Changes in Post-harvest Quality of Menthe and Sage fresh Cut Herbs Treated with Citric acid, Salicylic Acid and Chitosan under Cold storage

\title{
A. Nazmy Abdel-Hamid
}

Medicinal and Aromatic Plants, Hort. Dept., Fac. Agric., Ain Shams University, Cairo, Egypt Received: 20 Nov. 2019 / Accepted 30 Jan. 2020 / Publication date: 20 Feb. 2020

\begin{abstract}
The effect of citric acid, salicylic acid and chitosan as pre-storage treatments on store ability of fresh cut herbs of Menthe (Menha piperita L.) and Sage (Saliva officinalis L.) during 2018 and 2019 seasons were studied.

The fresh cut herbs of both species were stored for 15 days at $5^{\circ} \mathrm{C}$ followed by 5 days at $20^{\circ} \mathrm{C}$ as a marketing conditions simulation. Physical properties, chemical constituents and volatile oil contents were evaluated.

Weight loss \%, discarded herb \% and external appearance in both herbs greatly affected with different treatments and cold storage durations and the great effect in this respect was obtained with salicylic acid at $1.0 \mathrm{mM}$ and chitosan at $1000 \mathrm{ppm}$. However, a great values in total chlorophyll, Lascorbic acid, total phenol and total flavones due to the applied treatments compared with control in menthe and sage herbs were recorded during cold storage at $5^{\circ} \mathrm{C}$ for 15 days followed by marketing durations at $20^{\circ} \mathrm{C}$ for 5 days. On contrary, an evident decrease in total acidity was observed with advanced in cold storage periods and due to the applied treatments compared with control in both herbs, during cold storage at $5^{\circ} \mathrm{C}$ for 15 days and during marketing durations at $20^{\circ} \mathrm{C}$ for 5 days. Additionally, an evident decrease in total acidity was observed with advanced in cold storage periods and due to the applied treatments compared with control.

In other side of view, electrolyte leakage and respiration rate values were controlled with applied treatments than untreated herbs either at cold storage at $5^{\circ} \mathrm{C}$ for 15 days or during marketing period at $20^{\circ} \mathrm{C}$ for 5 days. Volatile oil of both menthe and sage fresh cut herbs greatly affect with cold storage duration at $5^{\circ} \mathrm{C}$ for 15 days and followed by 5 days at $20^{\circ} \mathrm{C}$. However, volatile oil of menthe fresh cut herb ranged from $0.22-0.27 \%$ and from $0.31-0.36 \%$ in sage herbs.
\end{abstract}

Keywords: Menthe, Sage, fresh cut herb, cold storage appearance, respiration rate, storage ability, volatile oil.

\section{Introduction}

Lamiaceae family having 25 species (Orphanides et al., 2013), Mentha mint is one of the most well-known herbs of across the board applications in corrective, pharmaceutical and especially nourishment enterprises. Its health promoting and recuperating properties, alongside the trademark reviving fragrance, makes mint one of the most attractive herbs for use in different plates of mixed greens just as flavor and trimming in foods. Notwithstanding, the short-lived nature of new herbs makes their taking care of troublesome and trying for an all-inclusive timeframe. Handling strategies of fresh cut herbs and stripping of new produce incite breath rate and trigger quicker water misfortune by tissue injuring. The subsequent layer damage stimulates enzymatic cooking, oxidative responses and helplessness to microbial development. Limiting the postharvest misfortunes can give nourishment accessibility to the developing total populace, decline the zone required for creation and ensure the characteristic assets (Kader and Rolle 2004).

Sage (Salvia officinalis L.) is a multipurpose culinary herb that has a place with the family Lamiaceae/Labiatae and is known as nursery savvy or normal wise or culinary sage. It is a fragrant perpetual woody sub-bush local toward the northern Mediterranean area and generally disseminated over the slopes and shores of southern Europe. It is developed all through Europe and the USA, including Spain, Italy, Yugoslavia, Greece, Albania, Argentina, Germany, France, Malta, Turkey, England and Canada (Glisic et al., 2010 \& Prakash, 1990 ). Its utilization as a culinary herb has encouraged its spread into numerous nations, and now it is developed all through the world for dried

Corresponding Author: A. Nazmy Abdel-Hamid, Medicinal and Aromatic Plants, Hort. Dept., Fac. Agric., Ain Shams University, Cairo, Egypt 
leaves or fresh cut herbs utilized as crude material for medication, perfumery and nourishment enterprises (Gomes et al., 2002). Sage is overwhelmingly perceived as a culinary herb in western cooking and was utilized in poultry stuffing, seasoning of meat, hotdogs, and fish. Fundamental oil of sage was utilized in aromas, antiperspirants, insecticidal medications, for thrush, gum disease and as a calmative (Prakash, 1990 \& Ghorbani and Esmaeilizadeh, 2017). The herb is primarily used to improve the perception and furthermore utilized in the treatment of cardiovascular ailments, over the top perspiring, anxious disarranges, melancholy, and cerebral ischemia and to lessen nursing mother's milk when weaning, additionally suggested for swishing irresistible throat and goes about as germicide for wounds (Hamidpour et al., 2014 \&. Lopresti, 2017).

Antioxidant or reducing agents prevent browning through reducing enzymatically formed quinones into the respective colorless diphenols. They may also react irreversibly with the quinones, forming more stable colorless compounds, such as ascorbic acid and its derivatives. The beneficial effect of the ascorbic acid is attributed to several aspects, such as capturing of oxygen and protection, forming a barrier that prevents oxygen diffusion toward the product, thus, reducing the production of quinones and inhibiting the PPO (Aguila et al., 2008). Citric acid may also be used as an antioxidant and chelating agent, acting synergistically with the ascorbic acid to chelate peroxidants, which may cause rancidity and inactivate enzymes such as the PPO (Wiley, 1994). The content of ascorbic acid of most vegetables decreases when bruising, trimming and cutting occurs (Lee \& Kader, 2000).

The application of SA, a natural phenolic compound with hormone-like function, reduced water loss, delayed discoloration, softening and decay in harvested commodity (Sayyari et al., 2009), and protected plant against pathogen attack (Ding et al., 2002). SA significantly reduced the quality loss and chilling disorders in fruits and herbs (Wang et al., 2006), However, SA and its derivatives are widely used to enhance pre- and postharvest quality of fruit and storage commodities by controlling firmness and appearance during storage (Valero et al., 2011)

Chitosan, a polysaccharides-based edible coating, has been successfully used to coat fresh-cut fruits and herbs (Ali et al., 2015 \& Bal, 2018). Also, chitosan has been applied successfully as coating on food surface to extend the shelf life effectively without compromising the natural tastes of product. The chitosan films are used as coating of fresh and fresh cut fruits and vegetable (apples, oranges, tomato, pepper, cantaloupe and fresh cut herbs) because they are flexible, offer valuable properties such as elasticity, selective permeability and act as antimicrobial barrier against pathogens (Hussein, Neama et al., 2015). However, an additional positive effect of chitosan coating is related to its ability to extend the storage life of fruits, vegetables and fresh cut herbs. Chitosan forms a semipermeable film that regulates the gas exchange and reduces transpiration losses and herb disordirs is slowed down. Also, respiration rate and hence water loss is reduced (Bautista - Banos et al., 2006). The respiration of fresh herbs can be reduced by many preservation techniques like low temperature, (Sandhya, 2010).

After harvesting and sorting, medicinal plants have three distinct destinations: sale of the fresh plants, extraction of their active components, or preservation by drying .Several factors affect the shelf-life of fresh plant products at the market including different varieties, cultivation, climatic factors during growth, the growth stage at harvest, and postharvest handling and conditions. Selection, cleaning, washing, trimming, sorting, measurement, peeling, curing, maturation, treatments with hormones, other agricultural inputs, and above all, packaging affect the quality of the product being sold (Wills et al., 2007).

The main target of this research are to evaluate the effect of citric acid, salicylic acid and chitosan as a pre - storage treatments on improving the ability of fresh cut herbs of Menthe (Mentha piperita L.) and sage (Saliva officnalis L.) during storage at $5 \pm 1{ }^{\circ} \mathrm{C}$ for 15 days followed by 5 days at $20 \pm 2{ }^{\circ} \mathrm{C}$ as a marketing condition simulation.

\section{Materials and Methods}

The percent work was conducted during 2018 and 2019 seasons in Hrot. Dept. Fac. Agric. Ain Shams Univ. on the fresh cut herbs of menthe (Mentha piperita L.) and sage (Saliva officnalis L.)

The aerial part of both menthe and sage plants (main aerial stem, branches and leaves) were cut in first of May in both studied seasons. The samples of herbs plants were obtained from a private farm located in Wadi El- Natron region Behira Governorate .After clean up and dipping in cold water 5 
munities the herbs were rinsed in percidine $(25 \mathrm{mg} / \mathrm{L}$ ) for 5 minutes (Yousefizad et al., 2015), then subjected to air drying, the percidine - treated herbs were dipped in distilled water and air dried . The cleaned herbs of both studied plants were adapted to $10 \mathrm{~cm}$ - branches and bundled in $50 \mathrm{gm}$. and subjected to pre - storage treatments for 5 minutes as follows :-

1.Control rinsed in distilled water

2. Citric acid at $100 \mathrm{ppm}$

3. Citric acid at $200 \mathrm{ppm}$

4. Salicylic acid at $0.5 \mathrm{mM}$

5. Salicylic acid at $1.0 \mathrm{mM}$

6. Chitosan at $1000 \mathrm{ppm}$

7.Chitosan at $2000 \mathrm{ppm}$

After finished from all treatments, the bundles were air dried packed in proliferated cellophane bags and held in foam dish. A completely randomized block design with 4 replicates was used, each replicate contained from 10 herb foam dishes $(7$ treatments $\times 4$ replicates $\times 10$ dishes $=280$ dishes for each herb specie. All dishes were stored at $5 \pm 1{ }^{\circ} \mathrm{C}$ for 15 days and $95 \%$ RH. followed by 5 days at $20 \pm 2{ }^{\circ} \mathrm{C}$ and $90 \% \mathrm{RH}$. as a marketing condition simulation. Initial sample from each herb specie was taken for different analysis.After that, samples were pull from cold storage at 5,10 and 15 days and subjected to different analysis whereas a part of sample (3 dishes) for each replicate was held at $20 \pm 2{ }^{\circ} \mathrm{C}$ for 5 days as a marketing conditions :-

The following parameters were evaluated:-

\section{Physical prosperities}

- Weight loss \%:- Herbs were weighed at the beginning of the experiment just after treatments application and every 5 days interval during the storage period. Weight loss was expressed as the percentage loss of the initial total weight.

- Discarded Herb \%:- The decayed herbs was periodically weighted and recorded, expressed as a percentage from the total weight of herb.

- External appearance (scale) :- was rated subjectively into one of five categories: 5 (excellent), 4 ( very good) , 3 (good), 2 (fair), and 1 (poor), by an informal panel of five people (Erkan et al., 2005)

\section{Chemical analysis :-}

- Total chlorophyll (as mg/100g fresh herb): was determined according to Nagata and Yamashta (1992).

- Total acidity (as g Citric acid/100 g fresh herb) was determined according to A.O.A.C. (2005).

- L-ascorbic acid content (mg/100g fresh herb) was determined following the methods by A.O.A.C. (2005).

- Lectrolyte leakage (\% EC leakage): Ten grams disks of the herb tissues were placed in a 100$\mathrm{ml}$ glass beaker containing $30 \mathrm{ml}$ of deionized water and magnetic stirred for $15 \mathrm{~min}$. Electrical conductivity (EC) of the stirred solution was measured using electrical conductivity meter. Stirred solution of each beaker was then replaced by equal volume $(30 \mathrm{ml})$ of deionized water for homogenizing the disks in a blender, and the aliquot was then used for measuring EC level as previously described. Percentage of solute leakage was then calculated as EC leakage using the following formula by Mirdehghan et al. (2007).

- Total phenoles (as mg/g dry herb): was measured according to Singleton and Rossi, (1965).

- Total flavonoes (as mg/g dry herb): was determined according to Dewanto et al. (2002).

\section{Respiration rate $(\mathrm{mg} \mathrm{CO} / \mathrm{kg}$ fresh herb $/ \mathrm{hr})$ :}

Carbon dioxide produced by herbs was determined after $10 \mathrm{hrs}$ finished from treatments and then every 5 days during storage until experiment termination. The air-flow was passed through concentrated $\mathrm{NaOH} 2$, to insure that air-flow is $\mathrm{CO}_{2}$ free, before passing into 1-liter jar fruit container (fruit ambient) one fruit/jar was considered as one replicate. The out-coming air-flow was then passed 
into $100 \mathrm{ml} \mathrm{NaOH}$ of $0.1 \mathrm{~N}$ for $1 \mathrm{~h}$. Such solution was then titrated against $0.1 \mathrm{~N} \mathrm{HCl}$ and $\mathrm{CO}_{2}$ levels produced by the fruits were then calculated as $\left(\mathrm{mg} \mathrm{CO}_{2} / \mathrm{kg}\right.$ fresh herb/hr)., according to A.O.A.C. (2005).

\section{Volatile oil content (\%):}

In the two herbs in both studied seasons, the essential oil was extracted by water distillation method according to Novak et al. (2002). The amount of obtained volatile oil was measured and oil percentage (\%) were measured according to Charles and Simon (1990).

\section{Statistical analysis}

Data were subjected to analysis of variance (ANOVA) using MSTAT-C software (MSTAT, Michigan University East Lansing). Duncan multiple rang test (LSR) was performed to determine any significant difference among various treatments. $\mathrm{p}<0.05$ was selected as decision for significant differences) according to Steel et al. (1997).

\section{Results and Discussion}

\section{I- Physical properties}

1- Weight loss \%

It is clear from data in Table (1) that all pre storage treatments greatly decreased weight loss $\%$ than control of Menthe and Sage fresh and herbs stored at $5^{\circ} \mathrm{C} \pm 1$ and $95 \%$. RH during 2018 and 2019 seasons.

Table 1: Effect of citric acid, salicylic acid and chitosan as pre storage treatments on weight loss \% of Menthe and Sage fresh cut herbs stored at $5 \pm 1{ }^{\circ} \mathrm{C}$ and $95 \% \mathrm{RH}$, followed by 5 days at $20 \pm 2{ }^{\circ} \mathrm{C}$ during 2018 and 2019 seasons.

\begin{tabular}{|c|c|c|c|c|c|c|c|c|}
\hline \multirow{3}{*}{ Treatments } & \multicolumn{4}{|c|}{ Menthe } & \multicolumn{4}{|c|}{ Sage } \\
\hline & \multicolumn{3}{|c|}{$\begin{array}{l}\text { Days in cold storage } \\
\left(5 \pm 1^{\circ} \mathrm{C}\right)\end{array}$} & \multirow{2}{*}{$\begin{array}{c}5 \text { days } \\
\text { at } \\
\left(20 \pm 2^{\circ} \mathrm{C}\right)\end{array}$} & \multicolumn{3}{|c|}{$\begin{array}{l}\text { Days in cold storage } \\
\qquad\left(5 \pm 1^{\circ} \mathrm{C}\right)\end{array}$} & \multirow{2}{*}{$\begin{array}{c}5 \text { days } \\
\text { at } \\
\left(20 \pm 2^{\circ} \mathrm{C}\right)\end{array}$} \\
\hline & 5 & 10 & 15 & & 5 & 10 & 15 & \\
\hline Control & $3.67 \mathrm{a}$ & $6.93 \mathrm{a}$ & $8.22 \mathrm{a}$ & -- & $3.08 \mathrm{ab}$ & $5.96 \mathrm{a}$ & $9.17 \mathrm{a}$ & $13.25 \mathrm{~b}$ \\
\hline Citric acid at $100 \mathrm{ppm}$ & $3.35 \mathrm{ab}$ & $5.26 \mathrm{bc}$ & $7.44 \mathrm{ab}$ & $14.28 \mathrm{a}$ & $2.95 \mathrm{ab}$ & $5.13 \mathrm{ab}$ & $6.88 \mathrm{~b}$ & $11.92 \mathrm{c}$ \\
\hline Salicylic acid at $0.5 \mathrm{mM}$ & $2.55 \mathrm{c}$ & $3.79 \mathrm{de}$ & $6.16 \mathrm{c}$ & $11.05 \mathrm{c}$ & $1.89 \mathrm{c}$ & $3.28 \mathrm{~cd}$ & $4.09 \mathrm{~d}$ & $10.11 \mathrm{~d}$ \\
\hline Salicylic acid at $1.0 \mathrm{mM}$ & $2.19 \mathrm{~cd}$ & $3.12 \mathrm{e}$ & $4.75 \mathrm{~d}$ & $9.14 \mathrm{~d}$ & $1.72 \mathrm{c}$ & $2.04 \mathrm{e}$ & $3.45 \mathrm{~d}$ & $7.89 \mathrm{e}$ \\
\hline Chitosan at 1000 ppm & $1.94 \mathrm{~d}$ & $3.84 \mathrm{de}$ & $4.33 \mathrm{~d}$ & $9.72 \mathrm{~d}$ & $1.55 \mathrm{c}$ & $2.85 \mathrm{de}$ & $3.16 \mathrm{~d}$ & $8.27 \mathrm{e}$ \\
\hline \multirow[t]{2}{*}{ Chitosan at 2000 ppm } & $3.74 \mathrm{a}$ & $6.03 \mathrm{ab}$ & $8.42 \mathrm{a}$ & -- & $3.25 \mathrm{a}$ & $4.95 \mathrm{~b}$ & $7.16 \mathrm{~b}$ & $15.74 \mathrm{a}$ \\
\hline & \multicolumn{8}{|c|}{2019 Season } \\
\hline Salicylic acid at $0.5 \mathrm{mM}$ & $2.74 \mathrm{c}$ & $5.71 \mathrm{~b}$ & $8.07 \mathrm{~b}$ & $13.21 \mathrm{~b}$ & $2.53 \mathrm{c}$ & $5.26 \mathrm{ab}$ & $6.17 \mathrm{c}$ & $10.20 \mathrm{c}$ \\
\hline Salicylic acid at $1.0 \mathrm{mM}$ & $2.51 \mathrm{c}$ & $4.12 \mathrm{c}$ & $5.30 \mathrm{c}$ & $8.97 \mathrm{c}$ & $2.07 \mathrm{~cd}$ & $3.94 \mathrm{~cd}$ & $4.74 \mathrm{~d}$ & $8.11 \mathrm{~d}$ \\
\hline Chitosan at $1000 \mathrm{ppm}$ & $2.47 \mathrm{c}$ & $4.31 \mathrm{c}$ & $5.71 \mathrm{c}$ & $9.20 \mathrm{c}$ & $1.74 \mathrm{~d}$ & $3.41 \mathrm{~d}$ & $5.20 \mathrm{~d}$ & $9.22 \mathrm{~d}$ \\
\hline Chitosan at 2000 ppm & $4.05 \mathrm{a}$ & $7.96 \mathrm{a}$ & -- & -- & $4.08 \mathrm{a}$ & $5.12 \mathrm{~b}$ & $8.14 \mathrm{ab}$ & $14.27 \mathrm{a}$ \\
\hline
\end{tabular}

-Values followed by the same letter (s) are not significantly different at 5\% level.

- The treatment was terminated due to discarded herb \% reached about $15 \%$.

Menthe fresh cut herbs exhibited less weight loss \% in all used treatments than control except the treatments of citric acid $100 \mathrm{ppm}$ and chitosan at $2000 \mathrm{ppm}$. The best treatment in this respect were salicylic acid at $1.0 \mathrm{mM}$ and chitosan at $1000 \mathrm{ppm}$ where recorded the least values of weight loss after 15 days of cold storage at $5^{\circ} \mathrm{C}$. However, marketing ability at $20^{\circ} \mathrm{C}$ for 5 days declare that the used treatments were effective and the treatments of salicylic acid at $1.0 \mathrm{mM}$ and chitosan at 1000 $\mathrm{ppm}$ were superior than others in reducing the rate of weight loss\%. Sage fresh herbs stored at $5^{\circ} \mathrm{C}$ recorded minimum values of weight loss $\%$ with al used treatments for 15 days than control. Salicylic 
acid at 0.5 or $1.0 \mathrm{mM}$ were effective than other treatments in reducing the lost of herb weight during cold storage. However, marketing duration for 5 days at $20^{\circ} \mathrm{C}$ recorded less values in weight loss $\%$ than control with all applied treatments except the treatment of 2000 ppm chitosan.

Leaves of Salvia officinalis L. (Lamiaceae) are used for both culinary and therapeutic purposes. They possess hypoglycemiant, spasmolytic, stomahic, estrogenic choleretic (Maniciula et al., 2013), antioxidant, ant-proliferative (Kontogiani et al., 2013), anti-inflammatory (Bauer et al., 2012) and gastro protective properties (Mayer et al., 2009). The phytochemical constituents of sage leaves include: flavonoids (luteolin, apigenin, quercetin-glycosides) (Roby et al., 2013), phenolcarboxylic acids (caffeic, chlorogenic, rosmarinic, ferulic), volatile oil (monoterpenic derivates), tannins, carnosol titter and triterpenic substances (Mayer et al., 2009).

\section{2- Discarded herb \%}

Cold storage of menthe and sage fresh cut herb at $5^{\circ} \mathrm{C}$ for 15 days followed by 5 days at $20^{\circ} \mathrm{C}$ (Table 2) greatly decreased discarded herb \%, with all applied treatments than control.

Table 2: Effect of citric acid, salicylic acid and chitosan as pre storage treatments on discarded \% of menthe and sage fresh cut herbs stored at $5 \pm 1{ }^{\circ} \mathrm{C}$ and $95 \% \mathrm{RH}$, followed by 5 days at $20 \pm 2{ }^{\circ} \mathrm{C}{ }^{\circ} \mathrm{C}$ during 2018 and 2019 seasons.

\begin{tabular}{|c|c|c|c|c|c|c|c|c|}
\hline \multirow{3}{*}{ Treatments } & \multicolumn{4}{|c|}{ Menthe } & \multicolumn{4}{|c|}{ Sage } \\
\hline & \multicolumn{3}{|c|}{$\begin{array}{l}\text { Days in cold storage } \\
\left(5 \pm 1^{\circ} \mathrm{C}\right)\end{array}$} & \multirow{2}{*}{$\begin{array}{c}5 \text { days } \\
\text { at } \\
\left(20 \pm 2^{\circ} \mathrm{C}\right)\end{array}$} & \multicolumn{3}{|c|}{$\begin{array}{l}\text { Days in cold storage } \\
\left(5 \pm 1^{\circ} \mathrm{C}\right)\end{array}$} & \multirow{2}{*}{$\begin{array}{c}5 \text { days } \\
\text { at } \\
\left(20 \pm 2^{\circ} \mathrm{C}\right)\end{array}$} \\
\hline & 5 & 10 & 15 & & 5 & 10 & 15 & \\
\hline & \multicolumn{8}{|c|}{2018 Season } \\
\hline Control & $2.14 \mathrm{a}$ & $10.56 \mathrm{a}$ & $21.09 \mathrm{a}$ & -- & $1.25 \mathrm{~b}$ & $6.94 \mathrm{a}$ & $13.20 \mathrm{a}$ & $19.83 \mathrm{~b}$ \\
\hline Citric acid at 100 ppm & $1.56 \mathrm{ab}$ & $4.63 \mathrm{~b}$ & $12.24 \mathrm{~b}$ & $17.19 \mathrm{a}$ & $0.78 \mathrm{bc}$ & $2.41 \mathrm{~b}$ & $7.33 \mathrm{~b}$ & $12.97 \mathrm{c}$ \\
\hline Citric acid at 200 ppm & $0.0 \mathrm{~d}$ & $2.79 \mathrm{bc}$ & $6.97 \mathrm{c}$ & $11.48 \mathrm{~b}$ & $0.0 \mathrm{c}$ & $1.26 \mathrm{bc}$ & $4.25 \mathrm{c}$ & $9.78 \mathrm{~cd}$ \\
\hline Salicylic acid at $0.5 \mathrm{mM}$ & $1.02 \mathrm{c}$ & $1.92 \mathrm{~cd}$ & $4.86 \mathrm{~cd}$ & $10.83 \mathrm{~b}$ & $0.0 \mathrm{c}$ & $0.75 \mathrm{c}$ & $2.93 \mathrm{~cd}$ & $7.71 \mathrm{de}$ \\
\hline Salicylic acid at $1.0 \mathrm{mM}$ & $0.0 \mathrm{~d}$ & $0.0 \mathrm{~d}$ & $2.11 \mathrm{e}$ & $4.15 \mathrm{~d}$ & $0.0 \mathrm{c}$ & $0.0 \mathrm{c}$ & $0.0 \mathrm{e}$ & $3.15 \mathrm{f}$ \\
\hline Chitosan at $1000 \mathrm{ppm}$ & $0.0 \mathrm{~d}$ & $0.0 \mathrm{~d}$ & $2.56 \mathrm{de}$ & $6.23 \mathrm{c}$ & $0.0 \mathrm{c}$ & $0.0 \mathrm{c}$ & $1.67 \mathrm{de}$ & 4.23 ef \\
\hline \multirow[t]{2}{*}{ Chitosan at 2000 ppm } & $1.53 \mathrm{bc}$ & $11.71 \mathrm{a}$ & $20.32 \mathrm{a}$ & -- & $2.54 \mathrm{a}$ & $8.26 \mathrm{a}$ & $13.53 \mathrm{a}$ & $25.57 \mathrm{a}$ \\
\hline & \multicolumn{8}{|c|}{2019 Season } \\
\hline Control & $3.26 \mathrm{~b}$ & $9.78 \mathrm{~b}$ & $23.51 \mathrm{a}$ & -- & $2.11 \mathrm{~b}$ & $5.58 \mathrm{a}$ & $10.97 \mathrm{a}$ & $17.47 \mathrm{a}$ \\
\hline Citric acid at $100 \mathrm{ppm}$ & $2.07 \mathrm{c}$ & $5.11 \mathrm{c}$ & $10.26 \mathrm{~b}$ & $21.97 \mathrm{a}$ & $0.0 \mathrm{c}$ & $3.52 \mathrm{~b}$ & $5.76 \mathrm{~b}$ & $11.18 \mathrm{~b}$ \\
\hline Citric acid at $200 \mathrm{ppm}$ & $0.0 \mathrm{~d}$ & $1.88 \mathrm{~d}$ & $4.34 \mathrm{c}$ & $11.52 \mathrm{~b}$ & $0.0 \mathrm{c}$ & $1.84 \mathrm{c}$ & $2.93 \mathrm{c}$ & $9.02 \mathrm{bc}$ \\
\hline Salicylic acid at $0.5 \mathrm{mM}$ & $0.0 \mathrm{~d}$ & $2.07 \mathrm{~d}$ & $4.23 \mathrm{c}$ & $12.75 \mathrm{~b}$ & $0.0 \mathrm{c}$ & $0.0 \mathrm{~d}$ & $1.77 \mathrm{~cd}$ & $6.14 \mathrm{~cd}$ \\
\hline Salicylic acid at $1.0 \mathrm{mM}$ & $0.0 \mathrm{~d}$ & $0.0 \mathrm{e}$ & $2.73 \mathrm{~d}$ & $5.37 \mathrm{c}$ & $0.0 \mathrm{c}$ & $0.0 \mathrm{~d}$ & $0.63 \mathrm{~d}$ & $2.73 \mathrm{e}$ \\
\hline Chitosan at 1000 ppm & $0.0 \mathrm{~d}$ & $0.0 \mathrm{e}$ & $3.16 \mathrm{~d}$ & $5.20 \mathrm{c}$ & $0.0 \mathrm{c}$ & $0.0 \mathrm{~d}$ & $0.0 \mathrm{~d}$ & $3.17 \mathrm{de}$ \\
\hline Chitosan at 2000 ppm & $4.56 \mathrm{a}$ & $16.57 \mathrm{a}$ & -- & -- & $3.37 \mathrm{a}$ & $6.75 \mathrm{a}$ & $11.55 \mathrm{a}$ & $20.11 \mathrm{a}$ \\
\hline
\end{tabular}

-Values followed by the same letter (s) are not significantly different at 5\% level.

- The treatment was terminated due to discarded herb \% reached about $15 \%$.

Untreated fresh cut herb of menthe recorded the highest values of discarded herb \% in both seasons followed by chitosan at $2000 \mathrm{ppm}$ during storage at $5^{\circ} \mathrm{C}$. The great effect in reducing discarded herb $\%$ in menthe after 15 days of cold storage at $5^{\circ} \mathrm{C}$ were recorded by salicylic acid at 1.0 $\mathrm{mM}$ and chitosan at $1000 \mathrm{ppm}$ in both studied seasons. However, during marketing at $20^{\circ} \mathrm{C}$, the least values of discorded herb \% were recorded by salicylic acid $1.0 \mathrm{mM}$ and chitosan at $1000 \mathrm{ppm}$ in both seasons. Discarded $\%$ of sage herb stored at $5^{\circ} \mathrm{C}$ were generally less than menthe herb. However, sage herb stored well at $5^{\circ} \mathrm{C}$ for 15 days either in control or with treated herbs, and the treatment of salicylic acid at $1.0 \mathrm{mM}$ in first season and chitosan at $1000 \mathrm{ppm}$ in second season were preserved the herb with no discarded $\%$ and good quality. Shelf life at $20^{\circ} \mathrm{C}$ for 5 days was superior with salicylic acid at $1.0 \mathrm{mM}$ and chitosan at $1000 \mathrm{ppm}$ where they recorded the least discarded herb \% in both seasons.

\section{3- External appearance (scale)}

Data in Table (3) show that menthe fresh cut herb stored at $5^{\circ} \mathrm{C}$ for 15 days exhibited high score of external appearance with all applied pre storage treatments than control. 
Table 3: Effect of citric acid, salicylic acid and chitosan as pre storage treatments on external appearance (scale) of menthe and sage fresh cut herbs stored at $5 \pm 1^{\circ} \mathrm{C}$ and $95 \% \mathrm{RH}$, followed by 5 days at $20 \pm 2{ }^{\circ} \mathrm{C}$ during 2018 and 2019 seasons.

\begin{tabular}{|c|c|c|c|c|c|c|c|c|}
\hline \multirow{3}{*}{ Treatments } & \multicolumn{4}{|c|}{ Menthe } & \multicolumn{4}{|c|}{ Sage } \\
\hline & \multicolumn{3}{|c|}{$\begin{array}{l}\text { Days in cold storage } \\
\qquad\left(5 \pm 1^{\circ} \mathrm{C}\right)\end{array}$} & \multirow{2}{*}{$\begin{array}{c}5 \text { days } \\
\text { at } \\
\left(20 \pm 2^{\circ}\right) \\
\end{array}$} & \multicolumn{3}{|c|}{$\begin{array}{l}\text { Days in cold storage } \\
\qquad\left(5 \pm 1^{\circ} \mathrm{C}\right)\end{array}$} & \multirow{2}{*}{$\begin{array}{c}5 \text { days } \\
\text { at } \\
\left(20 \pm 2^{\circ} \mathrm{C}\right)\end{array}$} \\
\hline & 5 & 10 & 15 & & 5 & 10 & 15 & \\
\hline & \multicolumn{8}{|c|}{2018 Season } \\
\hline Control & $4.53 \mathrm{~b}$ & $3.38 \mathrm{~d}$ & $2.05 \mathrm{~d}$ & & $5.00 \mathrm{a}$ & $3.45 \mathrm{~cd}$ & $2.78 \mathrm{c}$ & $1.93 \mathrm{e}$ \\
\hline Citric acid at $100 \mathrm{ppm}$ & $4.67 \mathrm{~b}$ & $3.69 \mathrm{~cd}$ & $2.57 \mathrm{~cd}$ & $1.87 \mathrm{~d}$ & $5.00 \mathrm{a}$ & $3.97 \mathrm{bc}$ & $3.54 \mathrm{~b}$ & $2.76 \mathrm{~d}$ \\
\hline Salicylic acid at $0.5 \mathrm{mM}$ & $5.00 \mathrm{a}$ & $4.33 \mathrm{~b}$ & $3.84 \mathrm{~b}$ & $3.16 \mathrm{~b}$ & $5.00 \mathrm{a}$ & $4.67 \mathrm{ab}$ & $4.47 \mathrm{a}$ & $3.68 \mathrm{~b}$ \\
\hline Salicylic acid at $1.0 \mathrm{mM}$ & $5.00 \mathrm{a}$ & $5.00 \mathrm{a}$ & $4.33 \mathrm{ab}$ & $3.87 \mathrm{a}$ & $5.00 \mathrm{a}$ & $5.00 \mathrm{a}$ & $4.40 \mathrm{a}$ & $4.07 \mathrm{a}$ \\
\hline Chitosan at 1000 ppm & $5.00 \mathrm{a}$ & $5.00 \mathrm{a}$ & $4.65 \mathrm{a}$ & $4.11 \mathrm{a}$ & $5.00 \mathrm{a}$ & $5.00 \mathrm{a}$ & $4.61 \mathrm{a}$ & $4.25 \mathrm{a}$ \\
\hline \multirow[t]{2}{*}{ Chitosan at 2000 ppm } & $4.72 \mathrm{ab}$ & $3.26 \mathrm{~d}$ & $2.47 \mathrm{~d}$ & & $4.33 \mathrm{~b}$ & $3.17 \mathrm{~d}$ & $2.56 \mathrm{c}$ & $1.78 \mathrm{e}$ \\
\hline & \multicolumn{8}{|c|}{2019 Season } \\
\hline Salicylic acid at $0.5 \mathrm{mM}$ & $5.00 \mathrm{a}$ & $5.00 \mathrm{a}$ & $3.97 \mathrm{~b}$ & $3.34 \mathrm{~b}$ & $5.00 \mathrm{a}$ & $5.00 \mathrm{a}$ & $4.20 \mathrm{ab}$ & $3.84 \mathrm{a}$ \\
\hline Salicylic acid at $1.0 \mathrm{mM}$ & $5.00 \mathrm{a}$ & $5.00 \mathrm{a}$ & $4.52 \mathrm{a}$ & $4.00 \mathrm{a}$ & $5.00 \mathrm{a}$ & $5.00 \mathrm{a}$ & $4.61 \mathrm{a}$ & $4.11 \mathrm{a}$ \\
\hline Chitosan at 1000 ppm & $5.00 \mathrm{a}$ & $5.00 \mathrm{a}$ & $4.39 \mathrm{ab}$ & $4.00 \mathrm{a}$ & $5.00 \mathrm{a}$ & $5.00 \mathrm{a}$ & $4.35 \mathrm{a}$ & $4.00 \mathrm{a}$ \\
\hline Chitosan at 2000 ppm & $4.00 \mathrm{~b}$ & $3.11 \mathrm{c}$ & -- & -- & $4.00 \mathrm{~b}$ & $3.25 \mathrm{c}$ & $2.71 \mathrm{c}$ & $2.07 \mathrm{c}$ \\
\hline
\end{tabular}

- Values followed by the same letter (s) are not significantly different at 5\% level.

- The treatment was terminated due to discarded herb \% reached about $15 \%$.

- Score - 5 (excellent), 4 (very good), 3 (good), 2 (fair), and 1 (poor).

The great effect in this respect were recorded with salicylic acid at $1.0 \mathrm{mM}$ and chitosan at $1000 \mathrm{ppm}$ where they recorded 4.33 and 4.65 score in first season, respectively. However, external appearance score were high in the same treatments and preserve the menthe herb with good quality. Additionally, sage fresh cut herb stored at $5^{\circ} \mathrm{C}$ for 15 days exhibited high external appearance score with all used treatments except the treatments of chitosan at $2000 \mathrm{ppm}$ which recorded the least external appearance score. However, the treatments of salicylic acid at both concentrations and chitosan at $1000 \mathrm{ppm}$ exhibited the highest external appearance score after 15 days of cold storage at $5^{\circ} \mathrm{C}$. The great effect to the applied treatments were continued with salicylic acid at $1.0 \mathrm{mM}$ and chitosan at $1000 \mathrm{ppm}$ during marketing at $20^{\circ} \mathrm{C}$ for 5 days.

The beneficial effect of the ascorbic acid is attributed to several aspects, such as capturing of oxygen and protection, forming a barrier that prevents oxygen diffusion toward the product, thus, reducing the production of quinones and inhibiting the polyphenoloxidase (PPO) (Aguila et al., 2008 ). However, citric acid may also be used as an antioxidant and chelating agent, acting synergistically with the ascorbic acid to chelate peroxidants, which may cause rancidity and inactivate enzymes such as the PPO (Wiley, 1994). The content of ascorbic acid of most vegetables and fresh cut herbs of medicinal and aromatic plants decreases when bruising, trimming and cutting occurs (Lee and Kader, 2000). A more effective preservation of color pigments in treated herbs can be achieved by using a combination of an antioxidant agent (ascorbic acid) and an acidulant (citric acid) (Ahvenainen, 2000).

\section{II- Chemical constituents}

\section{1- Total chlorophyll content (mg/100 g f.wt)}

It is clear from data in Table (4) that total chlorophyll of menthe fresh cut herb was higher with all applied treatments than control except the treatment of chitosan at $2000 \mathrm{ppm}$. The reduction of total chlorophyll in cold stored - herb was minimized with all treatments than control after 15 days of cold storage at $5^{\circ} \mathrm{C}$. The treatment of $1.0 \mathrm{mM}$ salicylic acid was superior than other treatments in preserve total chlorophyll of menthe fresh cut herb from loss after 15 days at $5^{\circ} \mathrm{C}$ in both seasons. 
However, during storage at $20^{\circ} \mathrm{C}$ for 5 days the treatments of $1.0 \mathrm{mM}$ salicylic acid and chitosan at $1000 \mathrm{ppm}$ were effective than others in keep the herb of menthe with high chlorophyll content.

Sage fresh cut herbs stored at $5^{\circ} \mathrm{C}$ and treated with different treatments kept with high chlorophyll content than control and the great effect was more pronounced with salicylic acid $1.0 \mathrm{mM}$ treatment than others. However, the treatment of $2000 \mathrm{ppm}$ of chitosan was similar to control in affecting chlorophyll content during cold storage at $5^{\circ} \mathrm{C}$. Marketing condition at $20^{\circ} \mathrm{C}$ declare that the treatments of $1.0 \mathrm{mM}$ salicylic acid and $1000 \mathrm{ppm}$ chitosan were effective in kept the chlorophyll content in sage herb than other treatments.

Table 4: Effect of citric acid, salicylic acid and chitosan as pre storage treatments on total chlorophyll content $(\mathrm{mg} / 100 \mathrm{~g} \mathrm{f.wt})$ of menthe and sage fresh cut herbs stored at $5 \pm 1{ }^{\circ} \mathrm{C}$ and $95 \% \mathrm{RH}$, followed by 5 days at $20 \pm 2{ }^{\circ} \mathrm{C}$ during 2018 and 2019 seasons.

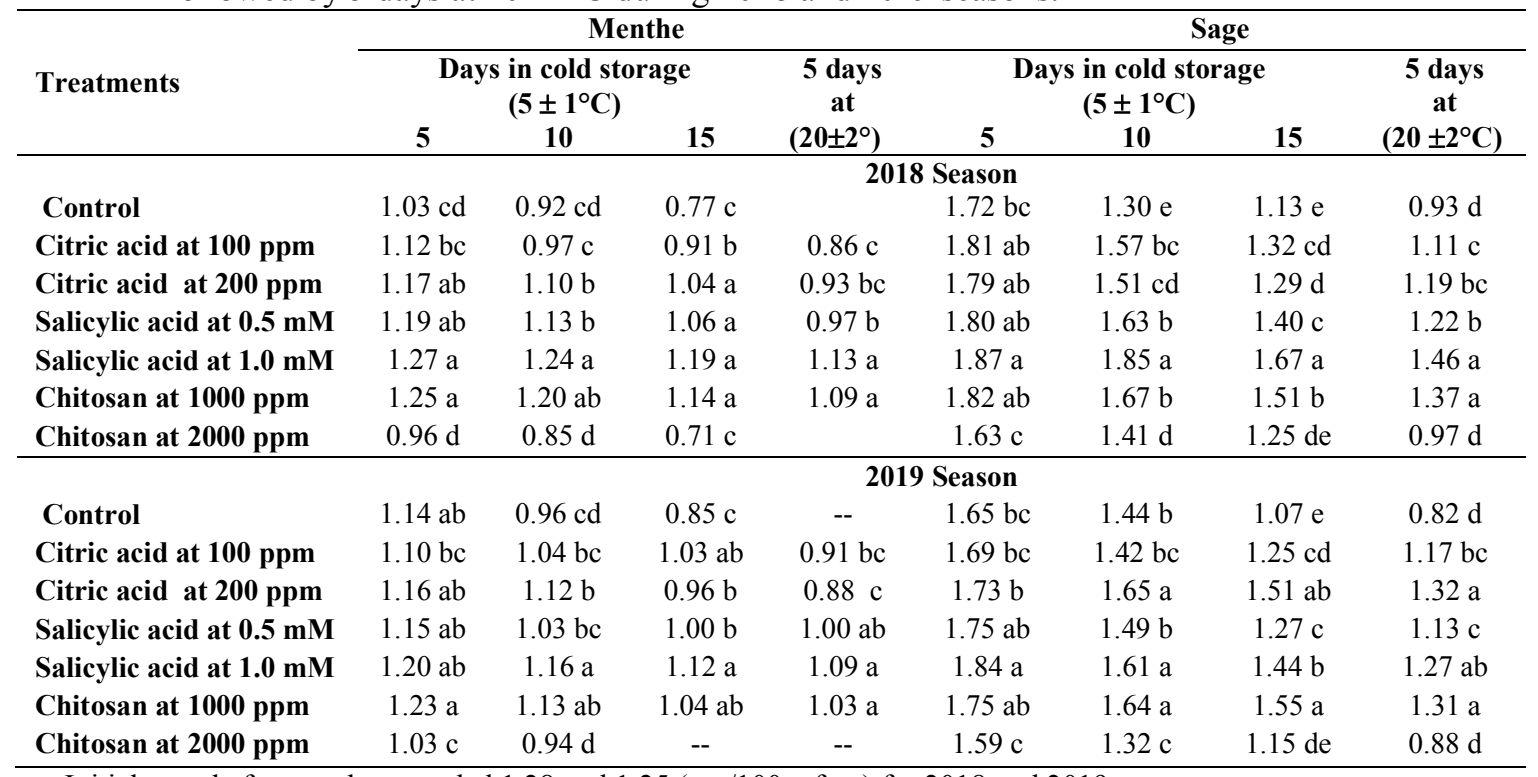

- Initial sample for menthe recorded 1.28 and 1.25 (mg/100 g f.wt) for 2018 and 2019 seasons.

- Initial sample for sage recorded 1.9 and 1.86 (mg/100 g f.wt) for 2018 and 2019 seasons.

- Values followed by the same letter (s) are not significantly different at $5 \%$ level.

- The treatment was terminated due to discarded herb \% reached about $15 \%$.

\section{2- Total acidity (g citric acid/100 g f.wt)}

Data in Table (5) show that all applied treatments reduced total acidity of menthe fresh cut herb stored at $5^{\circ} \mathrm{C}$ for 15 days than control. However, total acidity gradually decreased with advanced in cold storage duration regardless of the applied treatments. After 15 days of cold storage the treatments of $1000 \mathrm{ppm}$ chitosan in first season and $200 \mathrm{ppm}$ citric acid exhibited the higher values of total acidity. Total acidity values in sage fresh cut herb declare that $1.0 \mathrm{mM}$ of salicylic acid exhibited highest values than other treatments in first and second seasons during cold storage at $5^{\circ} \mathrm{C}$ for 15 days. However, during marketing at $20^{\circ} \mathrm{C}$ for 5 days, the same treatment of salicylic acid at $1.0 \mathrm{mM}$ exhibited higher values of total acidity in both studied seasons. It is well known that, the reduction of total acidity with advanced in cold storage duration attributed to consumption of these acids in respiration pathway.

\section{3- L-ascorbic acid (mg/100 g f.wt.)}

Data in Table (6) show that the reduction of L-ascorbic acid in menthe fresh cut herb during cold storage at $5^{\circ} \mathrm{C}$ for 15 days was less due to the applied treatments compared with control. After 15 days of cold-stored menthe herb, the highest values of L-ascorbic acid were recorded by salicylic acid at $1.0 \mathrm{mM}$ and chitosan at $1000 \mathrm{ppm}$ treatments. However, after 5 days of imitation marketing conditions at $20^{\circ} \mathrm{C}$, L-ascorbic acid content of menthe herbs were higher in salicylic acid at $1.0 \mathrm{mM}$ and chitosan at $1000 \mathrm{ppm}$ in both studied seasons than other treatments. L-ascorbic acid values in sage fresh cut herb was higher than menthe herb and exhibited highest values with salicylic acid at $1.0 \mathrm{mM}$ 
in first season after 15 days of cold storage at $5^{\circ} \mathrm{C}$ for 15 days. However, storage at $20^{\circ} \mathrm{C}$ to simulate marketing conditions declare that all used treatments recorded higher values of L-ascorbic acid than control except the treatment of $2000 \mathrm{ppm}$ of chitosan

Table 5: Effect of citric acid, salicylic acid and chitosan as pre storage treatments on total acidity ( $\mathrm{g}$ citric acid / $100 \mathrm{~g}$ f.wt.) $\%$ of menthe and sage fresh cut herbs stored at $5 \pm 1{ }^{\circ} \mathrm{C}$ and $95 \%$ RH, followed by 5 days at $20 \pm 2{ }^{\circ} \mathrm{C}$ during 2018 and 2019 seasons.

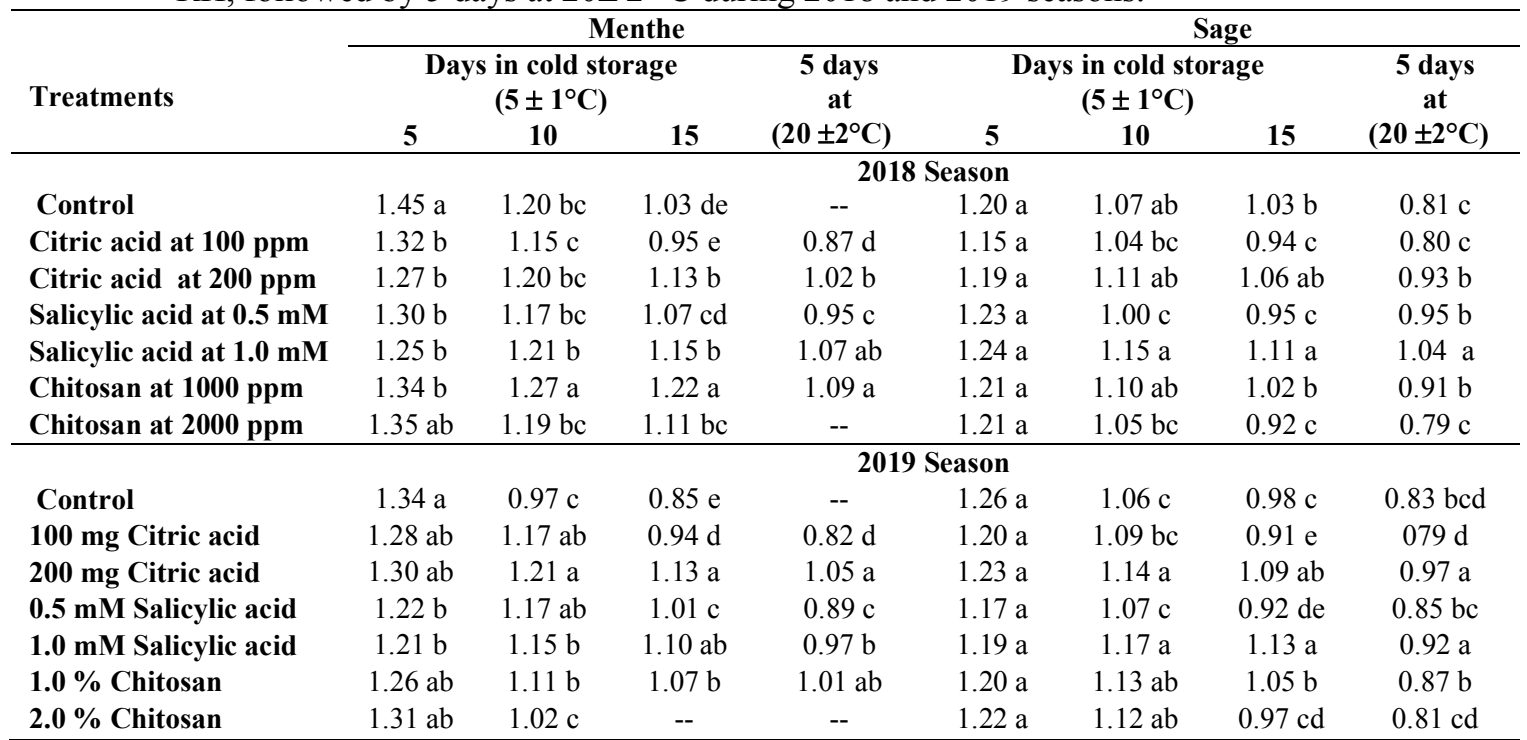

- Initial sample for menthe recorded 1.50 and 1.37 (g citric acid / $100 \mathrm{~g}$ f.wt.) for 2018 and 2019 seasons.

- Initial sample for sage recorded 1.26 and 1.29 (g citric acid / $100 \mathrm{~g}$ f.wt.) for 2018 and 2019 seasons.

- Values followed by the same letter (s) are not significantly different at $5 \%$ level.

- The treatment was terminated due to discarded herb \% reached about $15 \%$.

Table 6: Effect of citric acid, salicylic acid and chitosan as pre storage treatments on L- ascorbic acid (mg / $100 \mathrm{~g}$ f.wt.) of menthe and sage fresh cut herbs stored at $5 \pm 1^{\circ} \mathrm{C}$ and $95 \% \mathrm{RH}$, followed by 5 days at $20 \pm 2^{\circ} \mathrm{C}$ during 2018 and 2019 seasons.

\begin{tabular}{|c|c|c|c|c|c|c|c|c|}
\hline \multirow{4}{*}{ Treatments } & \multicolumn{4}{|c|}{ Menthe } & \multicolumn{4}{|c|}{ Sage } \\
\hline & \multirow{2}{*}{\multicolumn{3}{|c|}{$\begin{array}{l}\text { Days in cold storage } \\
\qquad\left(5 \pm 1^{\circ} \mathrm{C}\right)\end{array}$}} & \multicolumn{5}{|c|}{ Days in cold storage } \\
\hline & & & & \multirow{2}{*}{$\begin{array}{c}5 \text { days } \\
\text { at } \\
\left(20 \pm 2^{\circ} \mathrm{C}\right) \\
\end{array}$} & \multicolumn{3}{|c|}{$\left(5 \pm 1^{\circ} \mathrm{C}\right)$} & \multirow{2}{*}{$\begin{array}{c}5 \text { days } \\
\text { at } \\
\left(20 \pm 2^{\circ} \mathrm{C}\right) \\
\end{array}$} \\
\hline & 5 & 10 & 15 & & 5 & 10 & 15 & \\
\hline & \multicolumn{8}{|c|}{2018 Season } \\
\hline Control & $12.16 \mathrm{c}$ & $10.34 \mathrm{~d}$ & $8.11 \mathrm{c}$ & & $17.31 \mathrm{~d}$ & $15.10 \mathrm{~d}$ & $11.84 \mathrm{~d}$ & $9.71 \mathrm{e}$ \\
\hline Citric acid at $100 \mathrm{ppm}$ & $12.74 \mathrm{c}$ & $12.54 \mathrm{ab}$ & $9 . .96 \mathrm{~b}$ & $7.42 \mathrm{c}$ & $17.58 \mathrm{~d}$ & $16.43 \mathrm{bc}$ & $14.55 \mathrm{c}$ & $10.76 \mathrm{~d}$ \\
\hline Citric acid at $200 \mathrm{ppm}$ & $12.12 \mathrm{c}$ & $11.26 \mathrm{~cd}$ & $10.56 \mathrm{~b}$ & $8.73 \mathrm{c}$ & $18.18 \mathrm{~cd}$ & $16.22 \mathrm{c}$ & $14.42 \mathrm{c}$ & $12.66 \mathrm{c}$ \\
\hline Salicylic acid at $0.5 \mathrm{mM}$ & $13.09 \mathrm{bc}$ & $11.75 \mathrm{bc}$ & $10.24 \mathrm{~b}$ & $9.93 \mathrm{~b}$ & $18.91 \mathrm{bc}$ & $16.92 \mathrm{bc}$ & $15.15 \mathrm{c}$ & $12.50 \mathrm{c}$ \\
\hline Salicylic acid at $1.0 \mathrm{mM}$ & $14.46 \mathrm{a}$ & $13.20 \mathrm{a}$ & $12.43 \mathrm{a}$ & $11.07 \mathrm{a}$ & $20.11 \mathrm{a}$ & $18.01 \mathrm{a}$ & $17.75 \mathrm{a}$ & $15.17 \mathrm{a}$ \\
\hline Chitosan at 1000 ppm & $14.01 \mathrm{ab}$ & $12.74 \mathrm{ab}$ & $11.95 \mathrm{a}$ & $10.13 \mathrm{ab}$ & $19.32 \mathrm{ab}$ & $17.35 \mathrm{ab}$ & $16.21 \mathrm{~b}$ & $13.79 \mathrm{~b}$ \\
\hline \multirow[t]{2}{*}{ Chitosan at 2000 ppm } & $11.07 \mathrm{~d}$ & $9.54 \mathrm{~d}$ & $7.32 \mathrm{c}$ & & $18.03 \mathrm{~cd}$ & $15.10 \mathrm{c}$ & $12.25 \mathrm{~d}$ & $10.12 \mathrm{de}$ \\
\hline & \multicolumn{8}{|c|}{2019 Season } \\
\hline Control & $13.25 \mathrm{ab}$ & $10.07 \mathrm{~cd}$ & $7.25 \mathrm{c}$ & & $18.73 \mathrm{~cd}$ & $14.25 \mathrm{~d}$ & $10.75 \mathrm{e}$ & $8.25 \mathrm{~d}$ \\
\hline Citric acid at 100 ppm & $12.82 \mathrm{~b}$ & $11.73 \mathrm{ab}$ & $8.20 \mathrm{c}$ & $6.54 \mathrm{c}$ & $17.92 \mathrm{~d}$ & $15.27 \mathrm{~cd}$ & $\begin{array}{c}11.36 \\
\text { de }\end{array}$ & $9.32 \mathrm{c}$ \\
\hline Citric acid at 200 ppm & $13.20 \mathrm{ab}$ & $11.75 \mathrm{ab}$ & $9.52 \mathrm{~b}$ & $7.12 \mathrm{c}$ & $18.95 \mathrm{bc}$ & $16.27 \mathrm{c}$ & $14.03 \mathrm{c}$ & $11.74 \mathrm{~b}$ \\
\hline Salicylic acid at $0.5 \mathrm{mM}$ & $13.45 \mathrm{ab}$ & $12.05 \mathrm{a}$ & $10.53 \mathrm{a}$ & $9.11 \mathrm{~b}$ & $19.11 \mathrm{bc}$ & $17.44 \mathrm{~b}$ & $15.55 \mathrm{~b}$ & $12.12 \mathrm{~b}$ \\
\hline Salicylic acid at $1.0 \mathrm{mM}$ & $12.95 \mathrm{~b}$ & $10.73 \mathrm{bc}$ & $8.25 \mathrm{c}$ & $10.54 \mathrm{a}$ & $19.84 \mathrm{ab}$ & $16.20 \mathrm{c}$ & $15.72 \mathrm{~b}$ & $13.85 \mathrm{a}$ \\
\hline Chitosan at 1000 ppm & $13.71 \mathrm{ab}$ & $11.03 \mathrm{bc}$ & $9.57 \mathrm{ab}$ & $10.88 \mathrm{a}$ & $20.53 \mathrm{a}$ & $18.72 \mathrm{a}$ & $17.11 \mathrm{a}$ & $14.24 \mathrm{a}$ \\
\hline Chitosan at 2000 ppm & $14.08 \mathrm{a}$ & $9.25 \mathrm{~d}$ & & & $18.14 \mathrm{~cd}$ & $14.55 \mathrm{~d}$ & $12.30 \mathrm{~d}$ & $9.76 \mathrm{c}$ \\
\hline
\end{tabular}

- Initial sample for menthe recorded 15.00 and 14.32 (mg / $100 \mathrm{~g}$ f.wt.) for 2018 and 2019 seasons.

- Initial sample for sage recorded 20.23 and 21.02 (mg/ $100 \mathrm{~g}$ f.wt.) for 2018 and 2019 seasons.

- Values followed by the same letter (s) are not significantly different at $5 \%$ level $\%$.

- The treatment was terminated due to discarded herb \% reached about 15 . 
The application of SA, a natural phenolic compound with hormone-like function, reduced water loss, delayed discoloration, softening and decay in harvested commodity (Sayyari et al., 2009), and protected plant against pathogen attack (Ding et al., 2002). SA significantly reduced the quality loss and chilling disorders in fruits and herbs (Wang et al., 2006), However, SA and its derivatives are widely used to enhance pre- and postharvest quality of fruit and storage commodities by controlling firmness and appearance during storage (Valero et al., 2011).

\section{4- Electrolyte leakage (EC\%)}

It is clear from data in Table (7) that electrolyte leakage values were increased with advanced in cold storage durations at $5^{\circ} \mathrm{C}$ for 15 days in menthe and sage herbs fresh cut. However, as electrolyte leakage value increased, the discarded herb \% was increased and external appearance was decreased and consequently these parameters are considered as a good parameters to high quality of cold stored herbs. The least values of electrolyte leakage after 15 days of cold storage at $5^{\circ} \mathrm{C}$ in menthe herb were obtained with chitosan at $1000 \mathrm{ppm}$ in seasons. An evident increase in electrolyte leakage during marketing duration at $20^{\circ} \mathrm{C}$ for 5 days with all applied treatments except salicylic acid at 1.0 $\mathrm{mM}$ which was effective in preserving the herb with good quality.

Table 7: Effect of citric acid, salicylic acid and chitosan as pre storage treatments on electrolyte leakage (EC\%) of menthe and sage fresh cut herbs stored at $5 \pm 1{ }^{\circ} \mathrm{C}$ and $95 \% \mathrm{RH}$, followed by 5 days at $20 \pm 2{ }^{\circ} \mathrm{C}$ during 2018 and 2019 seasons.

\begin{tabular}{|c|c|c|c|c|c|c|c|c|}
\hline \multirow{3}{*}{ Treatments } & \multicolumn{4}{|c|}{ Menthe } & \multicolumn{4}{|c|}{ Sage } \\
\hline & \multicolumn{3}{|c|}{$\begin{array}{l}\text { Days in cold storage } \\
\left(5 \pm 1^{\circ} \mathrm{C}\right)\end{array}$} & \multirow{2}{*}{$\begin{array}{c}5 \text { days } \\
\text { at } \\
\left(20 \pm 2^{\circ}\right)\end{array}$} & \multicolumn{3}{|c|}{$\begin{array}{l}\text { Days in cold storage } \\
\left(5 \pm 1^{\circ} \mathrm{C}\right)\end{array}$} & \multirow{2}{*}{$\begin{array}{c}5 \text { days } \\
\text { at } \\
\left(20 \pm 2^{\circ} \mathrm{C}\right)\end{array}$} \\
\hline & 5 & 10 & 15 & & 5 & 10 & 15 & \\
\hline Control & $23.29 \mathrm{a}$ & $33.41 \mathrm{a}$ & $46.30 \mathrm{a}$ & & $20.09 \mathrm{ab}$ & $28.58 \mathrm{a}$ & $33.46 \mathrm{~b}$ & $64.79 \mathrm{~b}$ \\
\hline Citric acid at $100 \mathrm{ppm}$ & $23.41 \mathrm{a}$ & $28.30 \mathrm{~b}$ & $38.44 \mathrm{bc}$ & $73.40 \mathrm{a}$ & $20.44 \mathrm{a}$ & $26.07 \mathrm{~b}$ & $29.18 \mathrm{~cd}$ & $56.21 \mathrm{~cd}$ \\
\hline Salicylic acid at $0.5 \mathrm{mM}$ & $20.49 \mathrm{c}$ & $23.73 \mathrm{c}$ & $32.81 \mathrm{~d}$ & $63.15 \mathrm{c}$ & $18.55 \mathrm{~cd}$ & $22.38 \mathrm{c}$ & $26.74 \mathrm{de}$ & $53.87 \mathrm{~d}$ \\
\hline Salicylic acid at $1.0 \mathrm{mM}$ & $19.20 \mathrm{c}$ & $20.91 \mathrm{~d}$ & $30.30 \mathrm{de}$ & $52.76 \mathrm{e}$ & $17.37 \mathrm{~d}$ & $20.66 \mathrm{~d}$ & $25.78 \mathrm{e}$ & $42.01 \mathrm{e}$ \\
\hline Chitosan at $1000 \mathrm{ppm}$ & $17.18 \mathrm{~d}$ & $21.63 \mathrm{~d}$ & $27.63 \mathrm{e}$ & $56.10 \mathrm{~d}$ & $17.59 \mathrm{~d}$ & $21.19 \mathrm{~d}$ & $24.36 \mathrm{e}$ & $44.05 \mathrm{e}$ \\
\hline \multirow[t]{2}{*}{ Chitosan at 2000 ppm } & $23.86 \mathrm{a}$ & $28.92 \mathrm{~b}$ & $40.38 \mathrm{~b}$ & & $20.74 \mathrm{a}$ & $29.75 \mathrm{a}$ & $36.66 \mathrm{a}$ & $70.16 \mathrm{a}$ \\
\hline & \multicolumn{8}{|c|}{2019 Season } \\
\hline Citric acid at 200 ppm & $23.47 \mathrm{~b}$ & $30.29 \mathrm{~d}$ & $37.19 \mathrm{~b}$ & $62.53 \mathrm{~b}$ & $20.15 \mathrm{de}$ & $25.43 \mathrm{e}$ & $33.11 \mathrm{c}$ & $63.20 \mathrm{c}$ \\
\hline Salicylic acid at $0.5 \mathrm{mM}$ & $25.53 \mathrm{a}$ & $29.37 \mathrm{~d}$ & $34.12 \mathrm{c}$ & $60.11 \mathrm{bc}$ & $20.92 \mathrm{~cd}$ & $28.20 \mathrm{~b}$ & $35.32 \mathrm{bc}$ & $56.14 \mathrm{~d}$ \\
\hline Salicylic acid at $1.0 \mathrm{mM}$ & $21.30 \mathrm{c}$ & $27.19 \mathrm{e}$ & $36.27 \mathrm{bc}$ & $57.23 \mathrm{~cd}$ & $19.16 \mathrm{~d}$ & $26.22 \mathrm{~d}$ & $32.54 \mathrm{c}$ & $43.27 \mathrm{e}$ \\
\hline Chitosan at 1000 ppm & $23.23 \mathrm{~b}$ & $26.74 \mathrm{e}$ & $31.20 \mathrm{~d}$ & $55.12 \mathrm{~d}$ & $19.27 \mathrm{~d}$ & $24.46 \mathrm{e}$ & $29.17 \mathrm{~d}$ & $40.13 \mathrm{e}$ \\
\hline Chitosan at $2000 \mathrm{ppm}$ & $25.78 \mathrm{a}$ & $40.29 \mathrm{a}$ & -- & -- & $21.56 \mathrm{c}$ & $27.35 \mathrm{bc}$ & $41.57 \mathrm{a}$ & $74.11 \mathrm{a}$ \\
\hline
\end{tabular}

- Initial sample for menthe recorded 16.55 and 20.11 (EC\%) for 2018 and 2019 seasons.

- Initial sample for sage recorded 17.00 and $19.00(\mathrm{EC} \%)$ for 2018 and 2019 seasons.

- Values followed by the same letter (s) are not significantly different at 5\% level.

- The treatment was terminated due to discarded herb \% reached about $15 \%$.

Sage electrolyte leakage values showed that after 15 days of cold storage at $5^{\circ} \mathrm{C}$ the least values were recorded by chitosan at $1000 \mathrm{ppm}$ compared with other treatments or control. On the other hand, the treatment of $2000 \mathrm{ppm}$ of chitosan was deterioration treatment due to the increase of electrolyte leakage in both seasons. Moreover, the less values of electrolyte leakage during marketing period at $20^{\circ} \mathrm{C}$ for 5 days were recorded by salicylic acid at $1.0 \mathrm{mM}$ and chitosan at $1000 \mathrm{ppm}$ which were effective in increasing marketing ability of sage fresh cut herbs.

Salicylic acid is a phenolic compound is playing a main role in increasing the amount of antioxidants in the product, reduced ethylene production in harvested crops and fungicide effects is important directly on spoilage fungi (Asghar et al., 2015). Due to the large distances that the product 
generally must travel between the location of production and the shelflife of the consumer, the demand for postharvest techniques to maintain the quality of the fresh product for longer periods of time has grown (Wills et al., 2007).

\section{5- Total phenols (mg/g d.wt.)}

Data in (8) show that total phenols of menthe and sage fresh cut herbs stored at $5^{\circ} \mathrm{C}$ for 15 days followed by 5 days at $20^{\circ} \mathrm{C}$ greatly affected with cold storage duration and the applied treatments. Menthe total phenols values declare that the treatments of chitosan at $1000 \mathrm{ppm}$ in first season and salicylic acid at $1.0 \mathrm{mM}$ in second season were more effective than others in recording highest values in this respect.

However, after 5 days of storage at $20^{\circ} \mathrm{C}$ as simulation marketing conditions, highest total phenols values were recorded by chitosan at $1000 \mathrm{ppm}$ in both seasons of study. Sage fresh cut herbs exhibited higher values of total phenols than menthe herb as a general view. The treatments of salicylic acid at $1.0 \mathrm{mM}$ was effective than other treatments in recording highest values of total phenols after 15 days of cold storage at $5^{\circ} \mathrm{C}$ for 15 days. In addition, after 5 days of storage at $20^{\circ} \mathrm{C}$ as a similar condition to marketing chain, salicylic acid at $1.0 \mathrm{mM}$ in first season and citric acid at 200 $\mathrm{ppm}$ in second season were effective than others in recording higher values of total phenols.

Table 8: Effect of citric acid, salicylic acid and chitosan as pre storage treatments on total phenol (mg / g d.wt.) of menthe and sage fresh cut herbs stored at $5 \pm 1{ }^{\circ} \mathrm{C}$ and $95 \% \mathrm{RH}$, followed by 5 days at $20 \pm 2{ }^{\circ} \mathrm{C}$ during 2018 and 2019 seasons.

\begin{tabular}{|c|c|c|c|c|c|c|c|c|}
\hline \multirow{3}{*}{ Treatments } & \multicolumn{4}{|c|}{ Menthe } & \multicolumn{4}{|c|}{ Sage } \\
\hline & \multicolumn{3}{|c|}{$\begin{array}{l}\text { Days in cold storage } \\
\left(5 \pm 1^{\circ} \mathrm{C}\right)\end{array}$} & \multirow{2}{*}{$\begin{array}{c}5 \text { days } \\
\text { at } \\
\left(20 \pm 2^{\circ} \mathrm{C}\right) \\
\end{array}$} & \multicolumn{3}{|c|}{$\begin{array}{l}\text { Days in cold storage } \\
\left(5 \pm 1^{\circ} \mathrm{C}\right)\end{array}$} & \multirow{2}{*}{$\begin{array}{c}5 \text { days } \\
\text { at } \\
\left(20 \pm 2^{\circ} \mathrm{C}\right)\end{array}$} \\
\hline & 5 & 10 & 15 & & 5 & 10 & 15 & \\
\hline & \multicolumn{8}{|c|}{2018 Season } \\
\hline Control & $40.32 \mathrm{~d}$ & $38.11 \mathrm{bc}$ & $36.57 \mathrm{a}$ & -- & $71.75 \mathrm{bc}$ & $63.41 \mathrm{~cd}$ & $56.72 \mathrm{c}$ & $46.66 \mathrm{e}$ \\
\hline Citric acid at 100 ppm & $41.15 \mathrm{~cd}$ & $36.20 \mathrm{~d}$ & $31.56 \mathrm{~d}$ & $25.31 \mathrm{~d}$ & $72.15 \mathrm{bc}$ & $64.55 \mathrm{bc}$ & $57.34 \mathrm{c}$ & $50.11 \mathrm{~d}$ \\
\hline Citric acid at $200 \mathrm{ppm}$ & $42.56 \mathrm{ab}$ & $37.25 \mathrm{~cd}$ & $34.51 \mathrm{~b}$ & $29.66 \mathrm{~b}$ & $70.56 \mathrm{c}$ & $62.21 \mathrm{de}$ & $56.47 \mathrm{c}$ & $54.26 \mathrm{~b}$ \\
\hline Salicylic acid at $0.5 \mathrm{mM}$ & $42.75 \mathrm{ab}$ & $38.11 \mathrm{bc}$ & $30.59 \mathrm{~d}$ & $27.54 \mathrm{c}$ & $73.25 \mathrm{~b}$ & $66.10 \mathrm{~b}$ & $59.40 \mathrm{~b}$ & $51.83 \mathrm{~cd}$ \\
\hline Salicylic acid at $1.0 \mathrm{mM}$ & $41.16 \mathrm{~cd}$ & $36.74 \mathrm{~d}$ & $34.58 \mathrm{~b}$ & $31.44 \mathrm{a}$ & $77.38 \mathrm{a}$ & $69.45 \mathrm{a}$ & $65.11 \mathrm{a}$ & $59.74 \mathrm{a}$ \\
\hline Chitosan at 1000 ppm & $43.95 \mathrm{a}$ & $41.56 \mathrm{a}$ & $36.08 \mathrm{a}$ & $32.91 \mathrm{a}$ & $71.26 \mathrm{bc}$ & $65.27 \mathrm{bc}$ & $61.70 \mathrm{~b}$ & $53.20 \mathrm{bc}$ \\
\hline \multirow[t]{2}{*}{ Chitosan at 2000 ppm } & $41.85 \mathrm{bc}$ & $38.26 \mathrm{~b}$ & $33.45 \mathrm{c}$ & -- & $70.54 \mathrm{c}$ & $60.53 \mathrm{e}$ & $51.74 \mathrm{~d}$ & $44.71 \mathrm{e}$ \\
\hline & \multicolumn{8}{|c|}{2019 Season } \\
\hline Control & $37.90 \mathrm{~d}$ & $35.45 \mathrm{~b}$ & $31.75 \mathrm{ab}$ & -- & $70.49 \mathrm{~d}$ & $67.85 \mathrm{c}$ & $60.70 \mathrm{bc}$ & $48.00 \mathrm{~d}$ \\
\hline Citric acid at $100 \mathrm{ppm}$ & $38.27 \mathrm{~cd}$ & $34.39 \mathrm{c}$ & $29.67 \mathrm{~d}$ & $24.05 \mathrm{e}$ & $75.04 \mathrm{c}$ & $67.41 \mathrm{c}$ & $60.21 \mathrm{c}$ & $52.12 \mathrm{c}$ \\
\hline Citric acid at 200 ppm & $40.44 \mathrm{ab}$ & $35.44 \mathrm{~b}$ & $32.10 \mathrm{ab}$ & $28.18 \mathrm{c}$ & $74.07 \mathrm{c}$ & $66.57 \mathrm{c}$ & $61.78 \mathrm{bc}$ & $58.06 \mathrm{a}$ \\
\hline Salicylic acid at $0.5 \mathrm{mM}$ & $39.76 \mathrm{bc}$ & $35.45 \mathrm{~b}$ & $29.45 \mathrm{~d}$ & $26.17 \mathrm{~d}$ & $78.38 \mathrm{~b}$ & $71.39 \mathrm{~b}$ & $62.37 \mathrm{~b}$ & $55.46 \mathrm{~b}$ \\
\hline Salicylic acid at $1.0 \mathrm{mM}$ & $38.69 \mathrm{~cd}$ & $34.17 \mathrm{c}$ & $32.16 \mathrm{a}$ & $29.87 \mathrm{~b}$ & $81.25 \mathrm{a}$ & $73.62 \mathrm{a}$ & $67.72 \mathrm{a}$ & $55.86 \mathrm{~b}$ \\
\hline Chitosan at $1000 \mathrm{ppm}$ & $41.77 \mathrm{a}$ & $38.65 \mathrm{a}$ & $30.61 \mathrm{~cd}$ & $31.27 \mathrm{a}$ & $79.96 \mathrm{ab}$ & $67.88 \mathrm{c}$ & $66.02 \mathrm{a}$ & $54.80 \mathrm{~b}$ \\
\hline Chitosan at 2000 ppm & $39.35 \mathrm{bc}$ & $35.59 \mathrm{~b}$ & $31.11 \mathrm{bc}$ & -- & $68.43 \mathrm{~d}$ & $63.56 \mathrm{~d}$ & $54.33 \mathrm{~d}$ & $49.93 \mathrm{~d}$ \\
\hline
\end{tabular}

Among phenolic compounds, caffeic and chlorogenic acids are well known for their hepatoprotective and hypolipidaemic activity, through inhibition of lipid peroxidation and antioxidant properties (Karthikesan et al., 2010). Rosmarinic acid (2-hydroxi-dihydrocaffeic acid) has a wide spectrum of biological activities including anti-inflammatory, anti-microbial, antioxidant and immunomodulatory properties (Bruneton , 2005). Moreover, rosmarinic acid and caffeic acid have antidepressant and anxiolytic effects, through inhibition of monoaminoxidase activity and modulatory properties upon $\alpha 1$ - and $\alpha 2$ - adrenergic receptors (Takeda, 2003).

\section{6- Total flavones (mg/g d.wt.)}

Total flavones in fresh cut herbs of menthe and sage (Table 9) treated with different pre-storage treatments showed that both factors affected the content of total flavones. Menthe fresh cut herbs 
exhibited higher values of total flavones with applied treatments than control except the treatment of chitosan at $2000 \mathrm{ppm}$. Moreover, during marketing period at $20^{\circ} \mathrm{C}$ for 5 days, the higher total flavones was obtained with chitosan at $1000 \mathrm{ppm}$ in both seasons of study.

Sage fresh cut herb content of total flavones showed that after 15 days of cold storage at $5^{\circ} \mathrm{C}$, the treatment of salicylic acid at 1.0 exhibited the highest values of total flavones in both studied seasons than other treatments. However, the treatments of chitosan at $2000 \mathrm{ppm}$ recorded less values of total flavones than control in both studied seasons. Marketing period for 5 days at $20^{\circ} \mathrm{C}$ showed that the effect of salicylic acid at $1.0 \mathrm{mM}$ was continuous and recorded the highest values of total flavones in both seasons.

Table 9: Effect of citric acid, salicylic acid and chitosan as pre storage treatments on total Flavones (mg / g d.wt.) of menthe and sage fresh cut herbs stored at $5 \pm 1^{\circ} \mathrm{C}$ and $95 \% \mathrm{RH}$, followed by 5 days at $20 \pm 2{ }^{\circ} \mathrm{C}$ during 2018 and 2019 seasons.

\begin{tabular}{|c|c|c|c|c|c|c|c|c|}
\hline \multirow{3}{*}{ Treatments } & \multicolumn{4}{|c|}{ Menthe } & \multicolumn{4}{|c|}{ Sage } \\
\hline & \multicolumn{3}{|c|}{$\begin{array}{l}\text { Days in cold storage } \\
\left(5 \pm 1^{\circ} \mathrm{C}\right)\end{array}$} & \multirow{2}{*}{$\begin{array}{c}5 \text { days } \\
\text { at } \\
\left(20 \pm 2^{\circ}\right)\end{array}$} & \multicolumn{3}{|c|}{$\begin{array}{l}\text { Days in cold storage } \\
\left(5 \pm 1^{\circ} \mathrm{C}\right)\end{array}$} & \multirow{2}{*}{$\begin{array}{c}5 \text { days } \\
\text { at } \\
\left(20 \pm 2^{\circ} \mathrm{C}\right)\end{array}$} \\
\hline & 5 & 10 & 15 & & 5 & 10 & 15 & \\
\hline & \multicolumn{8}{|c|}{2018 Season } \\
\hline Control & $23.88 \mathrm{abc}$ & $20.43 \mathrm{~d}$ & $18.21 \mathrm{~d}$ & -- & $28.10 \mathrm{~d}$ & $26.73 \mathrm{c}$ & $21.51 \mathrm{~d}$ & $13.25 \mathrm{~d}$ \\
\hline Citric acid at 100 ppm & $23.57 \mathrm{bc}$ & $21.50 \mathrm{bcd}$ & $19.34 \mathrm{c}$ & $15.25 \mathrm{~d}$ & $29.07 \mathrm{~cd}$ & $27.56 \mathrm{bc}$ & $23.59 \mathrm{c}$ & $18.56 \mathrm{c}$ \\
\hline Citric acid at 200 ppm & $23.11 \mathrm{bc}$ & $21.95 \mathrm{bc}$ & $20.38 \mathrm{~b}$ & $17.36 \mathrm{c}$ & $28.25 \mathrm{~cd}$ & $26.11 \mathrm{c}$ & $24.20 \mathrm{c}$ & $19.17 \mathrm{c}$ \\
\hline Salicylic acid at $0.5 \mathrm{mM}$ & $22.57 \mathrm{c}$ & $22.08 \mathrm{~b}$ & $21.56 \mathrm{a}$ & $18.11 \mathrm{bc}$ & $32.11 \mathrm{ab}$ & $28.52 \mathrm{ab}$ & $26.43 \mathrm{ab}$ & $22.10 \mathrm{ab}$ \\
\hline Salicylic acid at $1.0 \mathrm{mM}$ & $25.74 \mathrm{a}$ & $23.91 \mathrm{a}$ & $21.74 \mathrm{a}$ & $18.28 \mathrm{ab}$ & $32.75 \mathrm{a}$ & $30.07 \mathrm{a}$ & $27.58 \mathrm{a}$ & $23.46 \mathrm{a}$ \\
\hline Chitosan at 1000 ppm & $24.97 \mathrm{ab}$ & $22.80 \mathrm{ab}$ & $21.56 \mathrm{a}$ & $19.13 \mathrm{a}$ & $30.15 \mathrm{bc}$ & $27.73 \mathrm{bc}$ & $24.95 \mathrm{bc}$ & $21.59 \mathrm{~b}$ \\
\hline \multirow[t]{2}{*}{ Chitosan at 2000 ppm } & $23.20 \mathrm{bc}$ & $20.53 \mathrm{~cd}$ & $17.21 \mathrm{~d}$ & -- & $28.25 \mathrm{~cd}$ & $23.51 \mathrm{~d}$ & $17.20 \mathrm{e}$ & $11.57 \mathrm{e}$ \\
\hline & \multicolumn{8}{|c|}{2019 Season } \\
\hline Control & $21.57 \mathrm{~cd}$ & $18.23 \mathrm{~cd}$ & $15.74 \mathrm{c}$ & -- & $30.75 \mathrm{bc}$ & $24.11 \mathrm{e}$ & $20.56 \mathrm{~d}$ & $14.12 \mathrm{e}$ \\
\hline Citric acid at 100 ppm & $24.59 \mathrm{a}$ & $19.32 \mathrm{c}$ & $17.20 \mathrm{~b}$ & $13.74 \mathrm{c}$ & $31.74 \mathrm{~b}$ & $26.32 \mathrm{de}$ & $23.20 \mathrm{c}$ & $20.17 \mathrm{~d}$ \\
\hline Citric acid at 200 ppm & $25.10 \mathrm{a}$ & $23.55 \mathrm{a}$ & $20.17 \mathrm{a}$ & $18.20 \mathrm{a}$ & $30.95 \mathrm{bc}$ & $27.30 \mathrm{~cd}$ & $25.14 \mathrm{~b}$ & $22.19 \mathrm{c}$ \\
\hline Salicylic acid at $0.5 \mathrm{mM}$ & $20.44 \mathrm{~d}$ & $18.10 \mathrm{~cd}$ & $16.34 \mathrm{~b}$ & $15.34 \mathrm{~b}$ & $34.23 \mathrm{a}$ & $31.55 \mathrm{a}$ & $27.33 \mathrm{a}$ & $24.25 \mathrm{a}$ \\
\hline Salicylic acid at $1.0 \mathrm{mM}$ & $24.32 \mathrm{ab}$ & $22.71 \mathrm{ab}$ & $20.13 \mathrm{a}$ & $17.73 \mathrm{a}$ & $35.91 \mathrm{a}$ & $30.74 \mathrm{ab}$ & $28.20 \mathrm{a}$ & $25.17 \mathrm{a}$ \\
\hline Chitosan at $1000 \mathrm{ppm}$ & $24.73 \mathrm{a}$ & $21.36 \mathrm{~b}$ & $19.20 \mathrm{a}$ & $18.50 \mathrm{a}$ & $32.07 \mathrm{~b}$ & $29.26 \mathrm{bc}$ & $26.11 \mathrm{~b}$ & $23.63 \mathrm{~b}$ \\
\hline Chitosan at 2000 ppm & $22.57 \mathrm{bc}$ & $17.10 \mathrm{~d}$ & -- & -- & $29.17 \mathrm{c}$ & $21.19 \mathrm{f}$ & $16.40 \mathrm{e}$ & $10.75 \mathrm{f}$ \\
\hline
\end{tabular}

- Initial sample for menthe recorded 27.32 and 25.84 (mg / g d.wt.) for 2018 and 2019 seasons.

- Initial sample for sage recorded 34.64 and 37.12 (mg / g d.wt.) for 2018 and 2019 seasons.

- Values followed by the same letter (s) are not significantly different at 5\% level .

- The treatment was terminated due to discarded herb \% reached about 15 .

After harvesting and sorting, medicinal plants have three distinct destinations: sale of the fresh plants, extraction of their active components and volatile oil or preservation by drying or cold storage .Several factors affect the shelf-life of fresh plant products at the market including postharvest handling and conditions. Selection, cleaning, washing, trimming, sorting, measurement, peeling, curing, maturation, treatments with hormones, other agricultural inputs, and above all, packaging affect the quality of the product being sold (Wills et al., 2007).

\section{7- Respiration rate ( $\mathrm{mg} \mathrm{CO} / \mathrm{kg}$ herb/ hr.)}

An evident increase in respiration rate with advanced in cold storage durations at $5^{\circ} \mathrm{C}$ was obtained with menthe and sage fresh cut herbs (Table 10). However, after 5 days of cold storage at $5^{\circ} \mathrm{C}$. an evident decrease in respiration rate was obtained with all applied treatments either in menthe or sage fresh cut herbs. On contrary, with advanced in cold storage durations and after 15 days all applied treatments decreased respiration rate and the treatments of chitosan at $1000 \mathrm{ppm}$ in menthe herb and salicylic acid at $1.0 \mathrm{mM}$ in sage herb were recorded the least values of respiration rate than other treatments. During marketing period at $20^{\circ} \mathrm{C}$ for 5 days a sharp increase in respiration rate was recorded in menthe or sage fresh cut herbs. However, the treatment of salicylic acid at $1.0 \mathrm{mM}$ was effective in recording the least respiration rate than other treatments. 
Table 10: Effect of citric acid, salicylic acid and chitosan as pre storage treatments on respiration rate (mg CO $2 / \mathrm{kg} / \mathrm{hr}$.). of menthe and sage fresh cut herbs stored at $5 \pm 1{ }^{\circ} \mathrm{C}$ and $95 \% \mathrm{RH}$, followed by 5 days at $20 \pm 2{ }^{\circ} \mathrm{C}$ during 2018 and 2019 seasons.

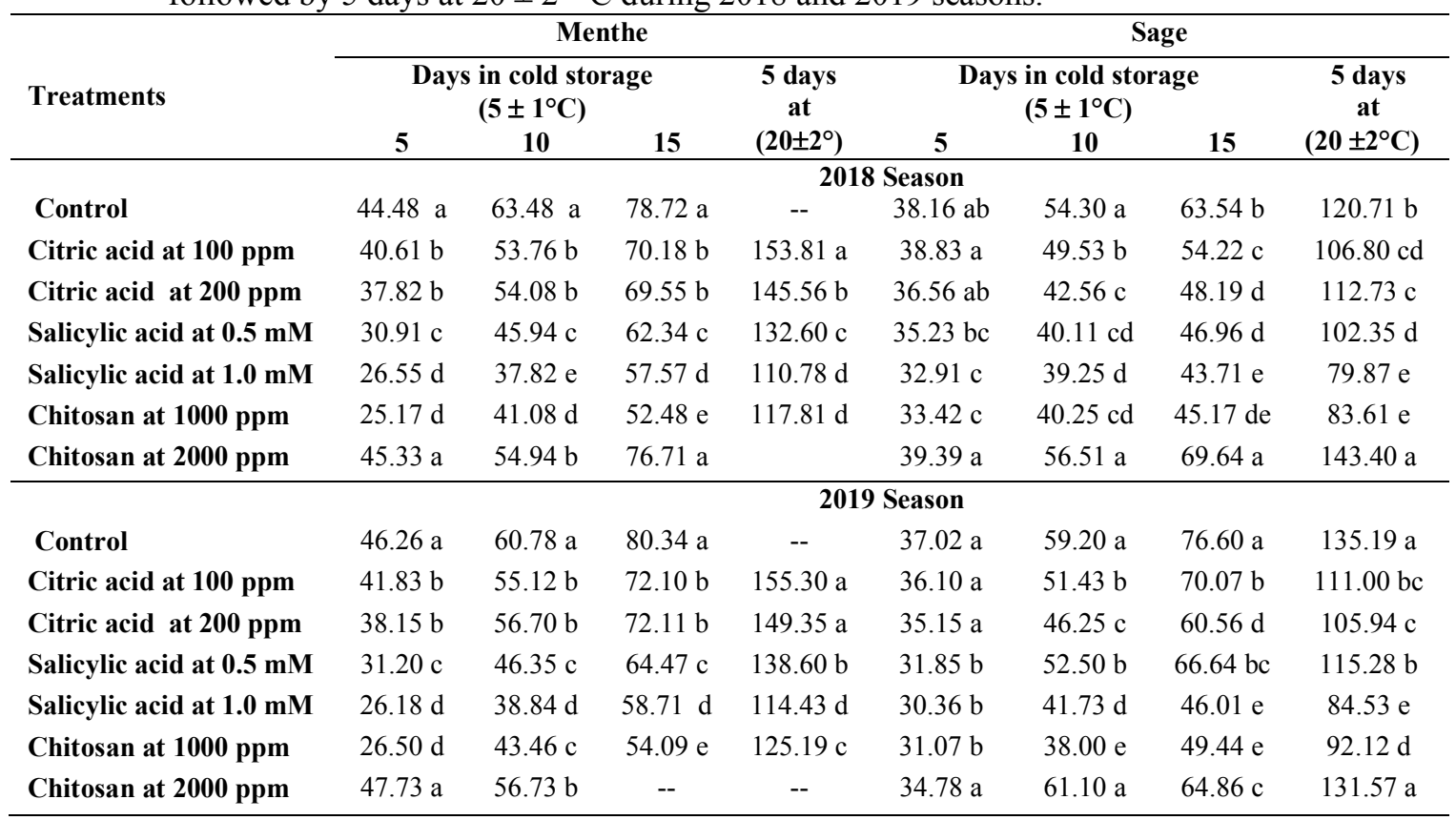

- Initial sample for menthe recorded 79.65 and 82.25 (mg CO2 / kg / hr). for 2018 and 2019 seasons.

- Initial sample for sage recorded 63.08 and 59.76 (mg CO2 / kg / hr).for 2018 and 2019 seasons.

- Values followed by the same letter (s) are not significantly different at 5\% level .

- The treatment was terminated due to discarded herb \% reached about $15 \%$.

Chitosan, a polysaccharides-based edible coating, has been successfully used to coat fresh-cut fruits and herbs (Ali et al 2015 and Bal, 2018). Also, chitosan has been applied successfully as coating on food surface to extend the shelf life effectively without compromising the natural tastes of product. The chitosan films are used as coating of fresh and fresh cut fruits and vegetable (apples, oranges, tomato, pepper, cantaloupe and fresh cut herbs) because they are flexible, offer valuable properties such as elasticity, selective permeability and act as antimicrobial barrier against pathogens (Hussein Neama et al., 2015). However, an additional positive effect of chitosan coating is related to its ability to extend the storage life of fruits, vegetables and fresh cut herbs. Chitosan forms a semipermeable film that regulates the gas exchange and reduces transpiration losses and herb disordirs is slowed down. Also, respiration rate and hence water loss is reduced (Bautista - Banos et al., 2006). The respiration of fresh herbs can be reduced by many preservation techniques like low temperature, (Sandhya, 2010).

\section{8- Volatile oil \%}

As it shown in Table (11), it is clear that volatile oil \% of menthe and sage fresh cut herbs greatly affected with cold storage durations and applied treatments After 15 days of cold storage at $5^{\circ} \mathrm{C}$, the highest values of volatile oil $(0.23 \%$ in menthe $)$ and $(0.32 \%$ in sage $)$ were obtained with salicylic acid at $1.0 \mathrm{mM}$ in first season of study. However, during marketing period at $20^{\circ} \mathrm{C}$ for 5 days, an evident decrease in volatile oil \% in both menthe and sage fresh cut herbs with all applied treatments but salicylic treatment at $1.0 \mathrm{mM}$ recorded the highest values of volatile $0.1 \%$. From general point of view volatile oil \% in menthe herb ranged from $0.22-0.27 \%$, whereas in sage herb ranged from $0.31-0.36 \%$.

Volatile oil of sage was used in perfumes, deodorants, insecticidal treatments, for thrush, gingivitis and as a calmative (Prakash, 1990 \& Ghorbani and Esmaeilizadeh, 2017). The herb is mainly used to improve the cognition and also used in the treatment of cardiovascular diseases, excessive sweating, nervous disorders, depression, and cerebral ischemia and to reduce nursing 
mother's milk when weaning, also recommended for gargling infectious throat and acts as antiseptic for wounds (Hamidpour et al 2014 \& Lopresti, 2017).

Table 11: Effect of citric acid, salicylic acid and chitosan as pre storage treatments on volatile oil \% of menthe and sage fresh cut herbs stored at $5 \pm 1{ }^{\circ} \mathrm{C}$ and $95 \% \mathrm{RH}$, followed by 5 days at $20 \pm 2{ }^{\circ} \mathrm{C}$ during 2018 and 2019 seasons.

\begin{tabular}{|c|c|c|c|c|c|c|c|c|}
\hline \multirow{3}{*}{ Treatments } & \multicolumn{4}{|c|}{ Menthe } & \multicolumn{4}{|c|}{ Sage } \\
\hline & \multicolumn{3}{|c|}{$\begin{array}{c}\text { Days in cold storage } \\
\left(5 \pm 1^{\circ} \mathrm{C}\right)\end{array}$} & \multirow{2}{*}{$\begin{array}{c}5 \text { days } \\
\text { at } \\
\left(20 \pm 2^{\circ} \mathrm{C}\right)\end{array}$} & \multicolumn{3}{|c|}{$\begin{array}{l}\text { Days in cold storage } \\
\qquad\left(5 \pm 1^{\circ} \mathrm{C}\right)\end{array}$} & \multirow{2}{*}{$\begin{array}{c}5 \text { days } \\
\text { at } \\
\left(20 \pm 2^{\circ} \mathrm{C}\right)\end{array}$} \\
\hline & 5 & 10 & 15 & & 5 & 10 & 15 & \\
\hline & \multicolumn{8}{|c|}{2018 Season } \\
\hline Control & $0.22 \mathrm{~cd}$ & $0.19 \mathrm{c}$ & $0.15 \mathrm{~d}$ & -- & $0.31 \mathrm{~d}$ & $0.27 \mathrm{c}$ & $0.22 \mathrm{~d}$ & $0.18 \mathrm{c}$ \\
\hline Citric acid at $100 \mathrm{ppm}$ & $0.24 \mathrm{bc}$ & $0.23 \mathrm{a}$ & $0.19 \mathrm{c}$ & $0.14 \mathrm{~d}$ & $0.32 \mathrm{~cd}$ & $0.30 \mathrm{~b}$ & $0.26 \mathrm{c}$ & $0.20 \mathrm{c}$ \\
\hline Salicylic acid at $0.5 \mathrm{mM}$ & $0.24 \mathrm{bc}$ & $0.22 \mathrm{ab}$ & $0.18 \mathrm{c}$ & $0.18 \mathrm{bc}$ & $0.34 \mathrm{bc}$ & $0.31 \mathrm{ab}$ & $0.27 \mathrm{bc}$ & $0.23 \mathrm{~b}$ \\
\hline Salicylic acid at $1.0 \mathrm{mM}$ & $0.27 \mathrm{a}$ & $0.24 \mathrm{a}$ & $0.23 \mathrm{a}$ & $0.21 \mathrm{a}$ & $0.36 \mathrm{a}$ & $0.33 \mathrm{a}$ & $0.32 \mathrm{a}$ & $0.27 \mathrm{a}$ \\
\hline Chitosan at 1000 ppm & $0.26 \mathrm{ab}$ & $0.24 \mathrm{a}$ & $0.22 \mathrm{ab}$ & $0.19 \mathrm{ab}$ & $0.34 \mathrm{bc}$ & $0.31 \mathrm{ab}$ & $0.29 \mathrm{~b}$ & $0.25 \mathrm{ab}$ \\
\hline Chitosan at 2000 ppm & $0.21 \mathrm{~d}$ & $0.18 \mathrm{c}$ & $0.14 \mathrm{~d}$ & -- & $0.33 \mathrm{~cd}$ & $0.27 \mathrm{c}$ & $0.22 \mathrm{~d}$ & $0.18 \mathrm{c}$ \\
\hline Citric acid at 200 ppm & $0.20 \mathrm{~d}$ & $0.18 \mathrm{bc}$ & $0.16 \mathrm{c}$ & $0.16 \mathrm{bc}$ & $0.34 \mathrm{~b}$ & $0.32 \mathrm{~b}$ & $0.29 \mathrm{~b}$ & $0.25 \mathrm{~b}$ \\
\hline Salicylic acid at $0.5 \mathrm{mM}$ & $0.23 \mathrm{bc}$ & $0.19 \mathrm{~b}$ & $0.17 \mathrm{~b}$ & $0.15 \mathrm{c}$ & $0.34 \mathrm{~b}$ & $0.30 \mathrm{~b}$ & $0.25 \mathrm{c}$ & $0.20 \mathrm{c}$ \\
\hline Salicylic acid at $1.0 \mathrm{mM}$ & $0.26 \mathrm{a}$ & $0.24 \mathrm{a}$ & $0.20 \mathrm{a}$ & $0.19 \mathrm{a}$ & $0.38 \mathrm{a}$ & $0.36 \mathrm{a}$ & $0.36 \mathrm{a}$ & $0.30 \mathrm{a}$ \\
\hline Chitosan at 1000 ppm & $0.26 \mathrm{a}$ & $0.23 \mathrm{a}$ & $0.19 \mathrm{ab}$ & $0.18 \mathrm{ab}$ & $0.35 \mathrm{~b}$ & $0.30 \mathrm{~b}$ & $0.27 \mathrm{bc}$ & $0.23 \mathrm{~b}$ \\
\hline Chitosan at 2000 ppm & $0.19 \mathrm{~d}$ & $0.16 \mathrm{c}$ & -- & -- & $0.31 \mathrm{c}$ & $0.25 \mathrm{c}$ & $0.19 \mathrm{~d}$ & $0.15 \mathrm{~d}$ \\
\hline
\end{tabular}

- Initial sample for menthe recorded 0.27 and $0.26 \%$ for 2018 and 2019 seasons

- Initial sample for sage recorded 0.36 and $0.38 \%$ for 2018 and 2019 seasons.

- Values followed by the same letter (s) are not significantly different at 5\% level.

- The treatment was terminated due to discarded herb \% reached about $15 \%$.

\section{References}

A.O.A.C. 2005. Official Methods of the Analysis of A.O.A.C. International1 $8^{\text {th }}$ Edition, Published by A.O.A.C. International. Maryland 20877 -2417. USA.

Aguila, J.S., F.F. Sasaki, L.S. Heiffig, O.E.M. Marcos, M.J. Trevisan, and R.A. Kluge, 2008 .Effect of Antioxidants in Fresh Cut Radishes During the Cold Storage .Brazilian Archives of Biology and Technology 51(6):1217-1223.

Ahvenainen, R., 2000. Minimal processing of fresh produce. In: Alzamora SM, Lopez-Malo A, Tapia MS (Eds) Minimally Processed Fruits and Vegetables, Aspen Publisher Inc, Gaithersburg, Maryland, pp 277-290.

Ali A., N.M. Noh and M.A. Mustafa, 2015. Antimicrobial activity of chitosan enriched with lemongrass oil against anthracnose of bell pepper. Food Packaging and Shelf Life, 3, 56-61.

Asgher M., M.I. Khan, N.A. Anjum and N.A. Khan, 2015. Minimizing toxicity of cadmium in plantsrole of plant growth regulators. Protoplasma, 252 399-413.

Bal, E., 2018. Postharvest application of chitosan and low temperature storage affect respiration rate and quality of plum fruits. Journal of Animal Science and Technology, 15, 1219-1230.

Bauer, J., J. Kuehnl, J.M. Rollinger, O. Scherer, H. Northoff, H. Stuppner, O. Werz and A. Koeberle, 2012. Carnasol and carnosic acids from Salvia officinal is inhibit microsomal prostaglandin E2 synthase-1.The Journal of Pharmacology and Experimental Therapeutics, 342(1): 169-176.

Bautista-Banos S., A.N. Hernandez-Lauzardo, M.G. Velazquez-del Valle, M. Hernandez-Lopez, E. Ait Barka and C.L. Wilson, 2006. Chitosan as a potential natural compound to control pre and postharvest diseases of horticultural commodities. Crop Protection, 25, 108-118.

Bruneton J., 2005. Pharmacognosie, Phytochimie, Plantes medicinales, TEC \& DOC, Paris; 249-250. 
Charles, D.J. and J.E. Simon, 1990. Comparison of extraction methods for the rapid determination of essential oil content and composition of basil (Ocimum spp.). J. Amer. Soc. Hort. Sci., 115(3): $458-462$.

Dewanto, V., X.Z. Adom and K.K. Liu, 2002. Thermal processing enhances the nutritional value of tomatoes by increasing total antioxidant activity. J Agri. Food Chem., 50:3010-3014.

Ding C. K., C. Wang, K.C. Gross and D.L. Smith, 2002. Jasmonate and salicylate induce the expression of pathogenesis-related-protein genes and increase resistance to chilling injury in tomato fruit. Planta, 214 895-901.

Erkan M., M. Pekmezci and C.Y. Wang, 2005. Hot water and curing treatments reduce chilling injury and maintain post-harvest quality of 'Valencia' oranges. International Journal of Food Science and Technology, 40, 91-96

Ghorbani A. and M. Esmaeilizadeh, 2017. Pharmacological properties of Salvia officinalis and its components. Journal of Traditional and Complementary Medicine, 7(4):433-440.

Glisic S., J.,Ivanovic, M. Ristic and D. Skala, 2010. Extraction of sage (Salvia officinalis L.) by supercritical $\mathrm{CO}_{2}$ : Kinetic data, chemical composition and selectivity of diterpenes. Journal of Supercritical Fluids., 52:62-70.

Gomes P.C., R.M. Seabra, P.B. Andeade and M.F. Ferreira, 2002. Phenolic antioxidant compounds produced by in vitro shoots of sage (Salvia officinalis L.) Plant Science, 162:981-987.

Hamidpour, M., R. Hamidpour, S. Hamidpour and M. Chemistry, 2014. Pharmacology and Medicinal Property of Sage Salvia to Prevent and Cure Illnesses such as Obesity, Diabetes, Depression, Dementia, Lupus, Autism, Heart Disease and Cancer. Journal of Traditional and Complementary Medicine, 4(2):82-88.

Hussein, Neama M., M. F.,AbdAllah, A.,Abou El-Yazied and E. Rawia brahim, 2015. Sweet Pepper Quality Maintenance: Impact of Hot Water and Chitosan. Egypt. Hort. 42(1): 471-491.

Kader, A.A. and S.S. Rolie, 2004. The role of post-harvest management in assuring the quality and safety of horticultural produce. FAO Agricultural Services Bulletin 152. Rome, Italy.

Karthikesan K., L. Pari and V.P. Menon, 2010. Anti hyperlipidemic effect of chlorogenic acid and tetrahydrocurcumin in rats subjected to diabetogenic agents. Chemico-Biological Interactions, 188(3): 643-650.

Kontogiani V.G., G. Tomic, I. Nikolic, S. Stosic- Grujicic, I. Stonovic, I.P. Gerothanassis and A.G. Tzakos, 2013. Phytochemical profile of Rosmarinus officinalis and Salvia officinalis extracts and correlation to their antioxidant and anti-proliferative activity. Food Chemistry, 136(1):120129.

Lee, S.K. and A.A. Kader, 2000. Preharvest and postharvest factors influencing vitamin C content of horticultural crops. Postharvest Biology and Technology, 20, 207-220.

Lopresti, A.L., 2017. Salvia Sage: A Review of its Potential Cognitive-Enhancing and Protective Effects. Drugs RD.; 17:53-64.

Maniciula D., C. Roba, I. Oprean and R. Misca-Barbu, 2013. Synthesis of ursolic acid dipeptide derivates with potential biological activity. Rev. Chim., 64(12):1454-1458

Mayer, B., C.H. Baggio, C.S. Freitasm, A.C. Dos Santos, A. Twardowschy, H. Horst, M.G. Pizzolatti, G.A. Micke, M. Heller, E.P. Dos Santos, M.F. Otuki and M.A. Marques, 2009. Gastro protective constituents of Salvia officinalis L. Fitoterapia, 80:421-426.

Mirdehghan, S.H., M. Rahemi, D. Martnez-Romero, J.M. Valverde, P.J. Zapata, M. Serrano and D. Valero, 2007. Reduction of pomegranate chilling injury during storage after heat treatment: role of polyamines. Postharvest Biol. Technol., 44, 19-25.

Nagata, M. and I. Yamashta, 1992. Simple method for simultaneous determination of chlorophyll and carotenoids in tomato fruits. J. Japan. Soc. Food Sci. Technol. (Nippon Shokuhin Kogyo Gakkaishi), 39(10): 925-928

Novak, J., L. Jan, P. Friedrich and M.F. Chlodwig, 2002. Essential oil compounds in a historical sample of marjoram (Origanum majorana L., Lamiaceae). Flavour and Fragrance Journal. 17: $175-180$.

Orphanides, A., V. Goulas, and V. Gekas, 2013. Effect of drying method on the phenolic content and antioxidant capacity of spearmint. Czech J. Food Sci., 31, 509-513.

Prakash, V., 1990. Leafy spices. CRC Press, Inc., Boca Raton, Florida, USA, 
Roby M.H., M.A. Sarhan, K.A. Selim and K.I. Khael, 2013. Evaluation of antioxidant activity, total polyphenols and phenolic compounds in thyme (Thymus vulgaris L.), sage (Salvia officinalis L.) and marjoram (Origanum majorana L.) extracts. Industrial Crops and Products, 43:827-831

Sandhya, L., 2010. Modified atmosphere packaging of fresh produce: Current status and future needs. LWT - Food Science and Technology, 43(3):381-392.

Sayyari M., M. Babalar, S. Kalantari, M. Serrano and M. Valero, 2009. Effect of salicylic acid treatment on reducing chilling injury in stored pomegranates. Postharvest Biology and Technology, 53: 152-154.

Singleton, V. and J.R. Rossi, 1965. Colorimetry of total phenolics with phosphomonolybdic_/ phosphotungstic acid reagents. Am. J. Enol. Vitic., 16, 144- 158.

Steel, R.G., J.H. Torrie and Q. Dickey, 1997. Principles and Procedures of Statistics. A Biometrical approach 3rd Ed. McGraw Hill Book Co. Inc. New York. USA

Takeda H., 2003. Caffeic acid produces anti depressive and/or anxiolytic-like effects through indirect modulation of the [alpha]1A-adrenoceptor system in mice. Clinical Neuroscience and Neuropathology, 14(7): 1067-1070.

Valero D., H.M. Diaz-Mula, P.J. Zapata, S. Castillo, F. Guillen, D. Martinez-Romero and M. Serrano, 2011. Postharvest treatments with salicylic acid, acetylsalicylic acid or oxalic acid delayed ripening and enhanced bioactive compounds and antioxidant capacity in sweet cherry. Journal of Agriculture and Food Chemistry, 59: 5483-5489.

Wang L., S. Chena, W. Kong, S. Li and D. Archbold, 2006. Salicylic acid pretreatment alleviates chilling injury and affects the antioxidant system and heat shock proteins of peaches during cold storage. Postharvest Biology and Technology, 41: 244-251.

Wiley, R.C., 1994. Minimally processed refrigerated fruits and vegetables. Chapman and Hall, New York.

Wills, R., B. Mcglasson, D. Graham and D. Joyce, 2007. Postharvest: an introduction to the physiology \& handling of fruit, vegetables \& ornamentals. 4ed. Wallingford: New South Wales University Press, $227 \mathrm{p}$.

Yousefizad, L., R. Fathi and F. Ghanbari 2015 . Effectiveness of $\mathrm{CaCl} 2$, Peppermint oil and salicylic acid treatments on shelf life extension of fresh mint during cold storage. Journal of Food Processing and Preservation, 39; 2639-2646. 